\title{
Monetary regimes and labour institutions: an alternative interpretation of the downward trend in exchange-rate pass- through in peripheral countries ${ }^{1}$
}

\author{
Martín Cherkasky and Martín Abeles
}

\begin{abstract}
In recent years, several empirical studies have documented the decline in exchange-rate pass-through in peripheral countries. Conventional wisdom has interpreted this trend - verified in the last two decades - as the result of greater central bank credibility stemming from the implementation of formal inflation-targeting regimes. This paper offers an alternative interpretation, in line with the structuralist tradition, as it examines other instrumental transformations, concurrent with the establishment of inflationtargeting regimes, including ubiquitous labour market flexibilization. Empirical estimates for a set of peripheral countries for the period 1994-2016 show a marked correlation between the intensity of the exchange-rate pass-through and the weakening of labour market institutions.
\end{abstract}

\section{Keywords}

Foreign exchange rates, monetary policy, employment, labour market, developing countries

JEL classification

E02, E31, E58, J50

\section{Authors}

Martín Cherkasky is a Research Assistant in the Economic Commission for Latin America and the Caribbean (ECLAC) office in Buenos Aires. Email: martin.cherkasky@cepal.org. Martín Abeles is Chief of the ECLAC office in Buenos Aires. Email: martin.abeles@ cepal.org.

The authors are grateful for the contributions and suggestions provided by Francisco Arroyo Marioli, Pablo Bortz, Pablo Chena, Ariel Dvoskin, Germán Feldman, Gabriel Porcile, Juan Manuel Telechea, Fernando Toledo, Sebastián Valdecantos and Soledad Villafañe, and for the assistance provided by Alicia Pita in building the databases. The authors assume sole responsibility for any errors or omissions in this document. 


\section{Introduction}

Economists started off with an unshaken faith in their science as the source of verifiable explanations. Inflation was explained by factors that could be manipulated, that is, by factors which could be adjusted without any change in people's self-definitions: the level of demand, levels of taxation, size of government deficit, growth of money supply.

At the beginning of the 1980s, we are more ready to ask ourselves whether inflation isn't largely fuelled by our political relations, in other words, in part by the self-definitions implicit in our dominant practices.

Charles Taylor ${ }^{2}$

With the proliferation of inflation-targeting regimes in recent decades - which include the setting up of flexible exchange-rate schemes - the analysis of the relationship between exchange-rate fluctuations and inflation has gained prominence. ${ }^{3}$ In inflation-targeting regimes, exchange-rate pass-through needs to be minimized so that greater exchange-rate volatility resulting from a freely floating exchange rate does not hinder the attainment of low and stable inflation. Several recent studies have shown a downward trend in exchange-rate pass-through coefficients, which may explain why monetary authorities in many countries have tamed their "fear of floating" in implementing monetary policy. ${ }^{4}$

There are essentially two sorts of explanations of this downward trend in the literature. The first focuses on the decline in exchange-rate pass-through of import prices (Campa and Goldberg, 2005). This explanation suggests that one of the main reasons for the decline in pass-through coefficients is a change in the composition of imports, with a shift towards products whose prices are less sensitive to exchange-rate fluctuations because of the market power of importing companies and price discrimination in international markets. This approach suggests that higher product differentiation allows importing companies to reduce profit margins in order to maintain market shares, which allows for a lower pass-through. ${ }^{5}$ Another reason is the increasingly important role of the costs of non-traded services (whose prices are less sensitive to the exchange rate) in the value of traded products in developing countries, as countries become richer (Frankel, Parsley and Wei, 2012).

The second sort of explanation examines the reduction in exchange-rate pass-through to consumer prices in general (not just import prices) and highlights the role of expectations (Gagnon and Ihrig, 2004; Choudhri and Hakura, 2006; Carrière-Swallow and others, 2016; Devereux and Yetman, 2010; Bailliu and Fujii, 2004). The relevant studies are based on the theory put forward by Taylor (2000), according to which, in a model of staggered price setting and imperfect competition, price increases tend to be smaller when there is low inflation and a lower perceived persistence of cost changes. In this context, the credibility of the monetary authority becomes vital. In a monetary regime in which the official inflation target acts as the nominal anchor of the economy, central bank credibility depends on how effective

2 Taylor, 1985, p. 115.

3 There are two basic requirements in inflation-targeting regimes: (i) the absence of fiscal dominance; and (ii) the absence of external dominance. A logical consequence of the first requirement is central bank independence, which typically goes hand in hand with fiscal rules, including legal limits on the monetization of fiscal deficits. The second requirement entails that monetary policy should not target real exchange rates (e.g. for the sake of export promotion). Hence, inflation-targeting monetary regimes come with the establishment of freely floating exchange-rate regimes. It should be noted, however, that managed floating exchange-rate schemes tend to prevail in practice, with monetary authorities commonly intervening to limit short-term exchange-rate volatility, allegedly without interfering with the market determination of the real exchange rate in the long run.

4 Some authors suggest that central banks' "fear of floating" is due to "fear of inflation", especially in countries where exchange-rate pass-through is high (Schönerwald da Silva and Vernengo, 2008). In countries with floating exchange rates, this "fear of inflation" manifests as a relatively stricter policy response for limiting or containing depreciations compared with appreciations. In Latin America, this asymmetric policy response to exchange-rate movements seems to be more significant in countries such as Brazil and Mexico (Libman, 2018).

5 This explanation is based on pricing-to-market theory (Dornbusch, 1987; Krugman, 1987; and Marston, 1990). 
the monetary authority is perceived to be in meeting its goal (Choudhri and Hakura, 2001). A "credible" central bank is one which lets the official target guide agents' inflationary expectations, regardless of exchange-rate fluctuations. Several studies have illustrated the statistical significance of monetary policy credibility in explaining lower exchange-rate pass-through in developing countries in recent years (Carrière-Swallow and others, 2016; Borensztein and Queijo von Heideken, 2016). ${ }^{6}$

Exchange-rate pass-through to consumer prices can be broken down into two rounds: a so-called first-round effect, which involves the impact of nominal exchange-rate variations on the prices of tradable goods and services that are directly or indirectly included in household consumption baskets; and a second-round effect, which involves the impact of nominal exchange-rate variations on the rest of the prices of goods and services. ${ }^{7}$ The strength of the second-round effect depends on the capacity (market power) of suppliers of those goods and services to recover the loss (directly or indirectly) inflicted by inflation in tradables. Wage adjustment may account for a significant share of that loss. Workers' purchasing power is typically hit hard by exchange-rate depreciations. Assuming operative real wage resistance, the intensity of its inflationary (second-round) effect will ultimately depend on employers' ability to pass the increase in wage costs on to retail prices. ${ }^{8}$

From a macroeconomic perspective, there is a direct relationship between the strength of exchange-rate pass-through to domestic prices and real wage resistance. The conventional wisdom is that, such resistance - as well as the ability of entrepreneurs to transfer rising costs to prices - depends on the economic cycle, in which monetary policy itself may play a major role. It also depends on levels of unionization and the type of labour market institutions prevalent in each country. Lower exchangerate pass-through is more likely the result of the weakening of trade unions, the retreat of certain labour market institutions, or a combination of both, than of an increase in central bank credibility. This paper provides empirical evidence to support this alternative interpretation.

This working hypothesis is in line with the structuralist approach, whose analysis of inflation ascribes a decisive role to the institutions that regulate the distributive conflict (Kalecki, 1971; Rowthorn, 1977; Frenkel, 1984; Noyola, 1956; Sunkel, 1958; Olivera, 1967; Vernengo, 2003). It also ties in with the debate on the drop in inflation during the great moderation (1987-2007), a period characterized by the weakening of workers' bargaining power. ${ }^{9}$ This approach highlights the type of institutional arrangements needed for the effective establishment of inflation targeting regimes. By transcending the strictly monetary sphere, this standpoint provides a better understanding of the relationship between the lower-inflation trend seen since the late 1980s, the weakening of labour market institutions and the concomitant fall in wage shares, in developed and developing countries alike. The importance given to labour market institutions in this paper is also found in other analytical frameworks, including the post-Keynesian perspective, the French Regulation School and the varieties of capitalism approach.

The article is divided into six sections, including this introduction. Section II presents an alternative interpretation to the traditional explanations of the decline in exchange-rate pass-through. Section III estimates the exchange-rate pass-through in rolling windows for a panel of 22 peripheral countries, based on the local projection method devised by Jordà (2005) and commonly used in the empirical literature (Carrière-Swallow and others, 2016; Caselli and Roitman, 2016). Section IV presents different approaches to operationalizing workers' bargaining power and puts forward a strategy for estimating

\footnotetext{
6 In Carrière-Swallow and others (2016) monetary policy credibility is proxied by the divergence of professional inflation forecasts; in Borensztein and Queijo von Heideken (2016), it is defined as the difference between expected inflation (also resulting from professional forecasts) and the central bank's inflation target.

7 First-round pass-through includes the inflationary effect of intermediate and final tradable goods and services that are used in the local production of consumer goods.

8 Real wage resistance is defined as the increase in nominal wages intended to offset, in part or in full, the loss of purchasing power resulting from past inflation.

9 Perry and Cline (2016) provide evidence of the critical role played by wage resistance in lowering inflation during the great moderation in the United States.
} 
wage resistance. Section $\vee$ assesses the statistical significance of the variables obtained in the previous stage in explaining exchange-rate pass-through, combined with a broader set of variables commonly used in the empirical literature. Section VI concludes.

\section{Exchange-rate pass-through, distributive conflict and wage resistance}

This paper adopts an alternative approach in the analysis of the decline in exchange-rate pass-through. In line with the structuralist approach, labour market institutions are conceived of as the most important factor in regulating the distributive conflict. Two statistical relationships are considered in order to assess the effects of currency devaluations on income distribution: (i) a static relationship between variables' absolute levels, so as to show the distributive changes resulting from a modification of the real exchange rate; and (ii) a dynamic relationship, to examine the role of distributional conflict between local stakeholders and, in particular, of wage resilience.

We begin by introducing a cost-push pricing equation, ${ }^{10}$ in which, following Bastian and Setterfield (2017), import goods are introduced in line with the "producer approach". ${ }^{11}$

$$
P=(1+\tau)\left(W a+e P_{f} b\right)
$$

Where $P$ denotes the price of the local good, $W$ is the nominal wage, $e$ is the nominal exchange rate, $P_{f}$ is the price of imported goods in foreign currency, $a$ and $b$ are the ratios for labour and imports, respectively, over the total product, and $\tau$ denotes the mark-up.

We then solve equation (2.1) and divide both sides by $P$ to express wages and the exchange rate in real terms.

$$
(1+\tau) W a=P-(1+\tau) e P_{f} b \Rightarrow(1+\tau) w a=1-(1+\tau) e_{b}^{R}
$$

Where $w$ denotes the real wage and $e^{R}$ is the real exchange rate.

Equation (2.2) shows the distributive changes caused by a change in the real exchange rate in two extreme cases, assuming international prices and the production structure remain unchanged:

(i) Endogenous wages and exogenous mark-up rate:

$$
\begin{gathered}
w=\frac{1-(1+\tau) e^{R} b}{(1+\tau) a} \\
\left.\frac{d w}{d e_{R}}\right|_{\tau=\bar{\tau}}=\frac{-b}{a}<0
\end{gathered}
$$

\footnotetext{
10 The presentation of price levels from a cost-push perspective is in line with the post-Keynesian, neo-Keynesian (Carlin and Soskice, 2006) and structuralist traditions.

${ }^{11}$ There are two approaches to modelling inflation in an open economy (Bastian and Setterfield, 2017): (i) the consumer approach, which treats imports as final goods (Blecker, 1989 and 2011); and (ii) the producer approach, which treats imports as intermediate goods (Bhaduri and Marglin, 1990; Taylor, 2004).
} 
(ii) Endogenous mark-up rate and exogenous wages:

$$
\begin{gathered}
\tau=\frac{1-\left(w a+e_{R} b\right)}{w a+e_{R} b} \\
\left.\frac{d \tau}{d e_{R}}\right|_{w=\bar{w}}=\frac{-b}{\left(w a+e_{R} b\right)^{2}}<0
\end{gathered}
$$

These two cases show that a change in the real exchange rate must be absorbed by the real wage, the mark-up rate, or a combination of both, given the cost structure and the international prices of imported goods. ${ }^{12}$ This is critical for differentiating between disinflation and the decline in exchange-rate pass-through. In the first case, wages, prices and exchange rates may increase at a steadily slower nominal rate as a result of better coordination of expectations (forcing each sector to reduce its income claims, but without a loss of real income); ${ }^{13}$ in the second case, lower exchange-rate pass-through to domestic prices necessarily implies that at least one local sector will experience some income loss after the currency devaluation (firms, workers or both).

This distinction is also important for understanding the role of macroeconomic policy. While setting a target during a disinflation process may facilitate the coordination of agents' expectations, without necessarily changing in income distribution, a decline in exchange-rate pass-through requires that at least one local sector reduce its real income. Hence, central bank credibility may reduce exchange-rate pass-through, provided that its expected response to a devaluation is a contractionary monetary policy, which increases unemployment and reduces the wage share. Alternatively, the credibility of disinflation measures may be based on the ability to diminish workers' bargaining power through labour market flexibilization. Cornwall (1990) and Setterfield (2006b) define the latter as "incomes policy based on fear".

Next, a two-equation system is used to illustrate the dynamic relationship between wages and prices after a devaluation in a conflicting claims framework. First, let the growth rate of nominal wages sought by trade unions depend on two elements: the difference between the desired real wage and the effective real wage, and inflation for the previous period (2.7a):

$$
\hat{w}_{t}=\mu_{1}\left(\omega_{w}-\omega_{t-1}\right)+\mu_{2} \hat{p}_{t-1}
$$

Where $\hat{w}_{t}$ is the rate of nominal wage increase, $\hat{p}_{t-1}$ is inflation in the previous period, $\omega_{w}$ is workers' desired real wage, $\mu_{1}$ is the parameter indicating how trade unions respond to the discrepancy between the desired real wage and the effective real wage, and $\mu_{2}$ is the parameter indicating to what extent unions can index wages on the basis of past inflation.

The first element reflects the gap in workers' income aspirations. It is positive insofar as workers are unable to attain what they consider fair wages because of partial indexation. The second reflects size indexation, i.e. the extent of real wage recovery after an increase in nominal prices, following the specifications suggested by Arestis and Sawyer (2005), Neville and Kriesler (2008) and Lavoie (2014), who postulate that unions, due to fundamental uncertainty, operate in an adaptive expectations environment. ${ }^{14}$

12 Dvoskin and Feldman (2015) examine the negative link between real wages and the real exchange rate, for a given profit rate, in various production structures in Latin America.

${ }^{13}$ In an ideal situation where there is consensus between workers and enterprises in the context of a "social bargain", it might be possible to reduce inflation without changing the functional distribution of income (Cornwall 1990; Cornwall and Cornwall, 2001; Setterfield, 2006b).

${ }^{14}$ If the second term in equation (2.7a) were replaced by a term denoting future expected inflation, there would be no change in the long-term equilibrium between inflation and real wages, which depends solely on the income aspiration gap. In other words, if the wage adjustment requested by workers is lower than past inflation because it is based on expectations of lower inflation in the future, the difference would be reflected in a greater increase in nominal wages in subsequent periods, owing to a wider gap between the desired real wage and the effective real wage. 
Parameters $\mu_{1}$ and $\mu_{2}$ represent workers' bargaining power and can be expressed as a function of other variables. In the expression proposed by Rochon and Setterfield (2007) and Vera (2014), workers' bargaining power depends on the unemployment rate. However, in Setterfield's specification (2006a), workers' bargaining power depends on institutional changes in the labour market.

Second, it is assumed that the inflation rate is affected by three factors: the income aspiration gap, wage costs and the cost of imported goods. The first component shows that firms have a target mark-up on unit production costs, which can be expressed in terms of real wages. ${ }^{15}$ The second component of the price equation corresponds to wage costs. For the sake of simplicity, labour productivity is assumed to remain constant so that changes in labour costs depend solely on nominal wages. ${ }^{16}$ The third and fourth components refer to the effect of changes in the nominal exchange rate and international prices of tradable goods.

$$
\hat{p}_{t}=\varphi_{1}\left(\omega_{t-1}-\omega_{f}\right)+\varphi_{2} \hat{w}_{t}+\varphi_{3} \hat{e}_{t}+\varphi_{4} \hat{p}_{f}^{t}
$$

Where $\hat{e}$ denotes nominal exchange-rate variation, $\varphi_{1}$ is the parameter indicating firms response to differences between the effective and the desired real wage, $\varphi_{2}$ is the parameter indicating the direct effect of labour costs on prices, $\varphi_{3}$ is the parameter indicating the direct effect of the exchange rate on inflation, and $\varphi_{4}$ denotes the direct effect of the international price of tradable goods.

In addition, the target real wages of workers and firms can be defined as depending on an exogenous component and the real exchange rate, in line with Bastian and Setterfield (2017).

$$
\begin{gathered}
\omega_{w}=\left[\omega_{w 0}+\mu_{2} e_{t-1}^{R}\right] \\
\omega_{f}=\left[\omega_{f 0}-\varphi_{2} e_{t-1}^{R}\right]
\end{gathered}
$$

This paper aims to weigh the effect of a devaluation on prices and wages, which amounts to estimating the effect of a temporary increase in the nominal exchange-rate variation over these variables. The shock can be assessed on the basis of two types of equilibrium: short-run and long-run equilibrium.

Short-run equilibrium may be defined as a position at which the shock's effect is reflected in the variables' variations over the short term, without necessarily reaching a stable relationship between the different variables. Under the above system, this equilibrium may be assumed to be achieved after one year, the typical interval for wage negotiations and adjustments.

Long-run equilibrium may be defined as a position at which variables return to a stable relationship after several periods of time $n$. In the system presented above, the income aspiration gap works as the attractor. A widening gap between worker's desired and effective real wages causes nominal wages to increase faster than prices and the nominal exchange rate, until the real wage returns to a stable position. If the real equilibrium wage is computed according to the above equations, considering solely the income aspiration gap (see annex A1), it can be shown that a change in the rate of variation in the nominal exchange rate, if temporary, does not affect the long-run real equilibrium wage (2.11).

\footnotetext{
15 This equation has been used by Dutt (1987), Sawyer (1982), L. Taylor (1985 and 1991), Sarantis (1990), Smithin (1994), Cassetti (2003), Setterfield (2006a and 2009) and Godley and Lavoie (2007), among other authors.

${ }^{16}$ If changes in labour productivity were taken into account, the income aspiration gap would have to be expressed in terms of the wage share in total income, so that changes in productivity would also be included in the distributional conflict between workers and enterprises.
} 


$$
\omega^{*}=\frac{\mu_{1} \omega_{w 0}+\varphi_{1} \omega_{f 0}+\left(\mu_{1} \mu_{2}-\varphi_{1} \varphi_{2}\right)\left[\frac{\left(\hat{e}+\hat{p}_{t}^{f}\right)\left(\mu_{1}+\varphi_{1}\right)-\mu_{1} \varphi_{1}\left(\omega_{w 0}-\omega_{f 0}\right)}{\mu_{1} \varphi_{1}\left(\mu_{2}+\varphi_{2}\right)}\right]}{\mu_{1}+\varphi_{1}}
$$

While long-run equilibrium is useful for analysing the trend of endogenous variables, it merely represents an ideal position, in which parameters are assumed to remain constant and are not affected by other shocks during the transition. Furthermore, the system described does not consider the interactions between distribution and employment and product, nor the equilibrium real exchange rate and its link to current account sustainability.

To simplify the analysis of a temporary increase in the nominal exchange rate, expressions (2.7a) and (2.8a) are adapted as (2.7b) and (2.8b), respectively, to represent a short-run equilibrium which shows the effect of devaluation on inflation without necessarily reaching stability. For this purpose, the terms associated with the income aspiration gap are replaced by constants $\left(\alpha_{0}\right.$ and $\left.\beta_{0}\right)$ so as to include their baseline level. This procedure assumes that inflation is determined only by nominal changes in costs and focuses attention on the dynamic relationship between prices and wages.

$$
\begin{gathered}
\hat{w}_{t}=\alpha_{0}+\alpha_{1} \hat{p}_{t-1} \\
\hat{p}_{t}=\beta_{0}+\beta_{1} \hat{e}_{t}+\beta_{2} \hat{w}_{t}+\beta_{3} \hat{p}_{t}^{f}
\end{gathered}
$$

Equation (2.7b) is then substituted into (2.8b), assuming short-run equilibrium as $\hat{p}_{t}=\hat{p}_{t-1}$ and solving for $\hat{p}_{t}$ :

$$
\hat{p}_{t}=\frac{\beta_{0}+\beta_{1} \hat{e}_{t}+\beta_{2} \alpha_{0}+\beta_{3 \hat{p}_{t} f}}{\left(1-\alpha_{1} \beta_{2}\right)}
$$

Lastly, we find the exchange-rate's time derivative as an approximation of exchange-rate pass-through.

$$
\frac{d \hat{p}_{t}}{d \hat{e}_{t}}=\beta_{1} \frac{1}{\left(1-\alpha_{1} \beta_{2}\right)}
$$

Two components can be distinguished in expression (2.13). The first is associated with the direct (or first-round) effect and is represented by the parameter $\beta_{1}$. This effect indicates the extent to which exchange-rate movements are passed on to consumer prices because of changes in tradable goods prices. The second component is associated with the indirect (or second-round) effect. This effect depends on wage resistance $\left(\alpha_{1}\right)$ and the weight of wages in unit production costs $\left(\beta_{2}\right){ }^{17}$ From a structuralist perspective, the direct effect of devaluation on domestic prices can be regarded as the shock that pushes inflation over its initial equilibrium, and the second-round effects - primarily related to wage negotiation - can be seen as the propagation mechanism (Noyola, 1956; Furtado, 1963).

This paper's hypothesis is that the decline in exchange-rate pass-through in recent decades is primarily attributable to lower wage resistance, which is explained by the reduction of workers' bargaining power resulting from both the weakening of labour market institutions and the mechanisms that push up unemployment. These include the policies pursued by central banks with a view to achieving their inflation targets.

\footnotetext{
${ }^{17}$ If the incidence of wages in unit production costs were to increase (accompanied by an equal and opposite decrease in the incidence of imports), and considering a pass-through of the price of imported products to consumer prices that exceeds wage resistance, the total pass-through of the exchange rate on consumer prices should decline.
} 
To empirically evaluate the importance of wage resistance in determining exchange-rate pass-through to prices, the following reasoning follows three steps: (i) estimation of exchange-rate pass-through in the sample; (ii) estimation of wage resistance; and (iii) regression of exchange-rate pass-through coefficients, using wage resistance coefficients and a set of control variables that are commonly used in the literature as explanatory variables.

\section{Evidence for the decline in exchange-rate pass-through}

\section{Estimation of total exchange-rate pass-through}

To calculate the accumulated response of internal prices for one year, the total exchange-rate pass-through is estimated using Jordà's local projection method (2005), a method used in recent studies measuring exchange-rate pass-through (Carrière-Swallow and others, 2016; Caselli and Roitman, 2016). The estimated specification is as follows:

$$
\begin{aligned}
& \operatorname{lnp}_{i, t+h-1}-\operatorname{lnp}_{i, t-1}=\beta_{0}+\sum_{j=0}^{j}\left(\beta_{1, j}^{h} N E E R_{i, t-j}\right)+\beta_{2}^{h} \text { energy }_{t}+ \\
& \beta_{3}^{h} \text { food }_{t}+\beta_{4, j}^{h} p_{i, t-1}+\beta_{5, j}^{h} \operatorname{gap}_{i, t}+\mu_{i, t}^{h}+\epsilon_{i, t}^{h}
\end{aligned}
$$

Where $p$ is the consumer price index, NEER is the logarithmic difference of the nominal effective exchange rate, energy and food are the logarithmic differences of the international price of energy and food, respectively, gap is the product gap, $\mu$ is a fixed effect per country, $\epsilon$ is an error term, $h$ is the projection timespan, $i$ denotes each of the countries included in the panel and $j$ the number of lags. The number of lags considered for the exchange rate is one $(j=1)$ and the selected projection timespan is four quarters $(h=4)$. This timespan (one year) is in line with the frequency of wage negotiations and adjustments, which is important when examining the second-round effects of exchange-rate variations. We are interested in $\beta_{1, j=0}^{h=4}$, which represents the one-year cumulative exchange-rate pass-through to consumer prices.

The local projection method estimates the effect of the explanatory variable in " $t$ " on the given variable in " $t+h$ ", where " $h$ " is the selected projection timespan. In this case, the dependent variable is expressed as the cumulative variation. The main advantage of the local projection method over the estimation using an autoregressive vector (VAR) model is that it is less sensitive to specification errors arising from introducing a growing number of regressors, lags and the projection timespan (Jordà, 2005; Teulings and Zubanov, 2014). The drawback is that the error term takes, by design, the structure of a moving average, introducing serial correlation and thus preventing standard statistical inference. Driscoll-Kraay standard errors are used to control for serial correlation. ${ }^{18}$

The specification uses the nominal effective exchange rate (NEER), a multicurrency indicator which covers more amply the scope of relative prices that affect the consumer price index (CPI). The use of the NEER is more relevant for countries that have weaker trading ties with the United States and whose trading partners' currencies are more volatile against the United States dollar. In these cases, the difference between the NEER and the bilateral nominal exchange rate (BNER) tends to be greater. ${ }^{19}$ The inclusion of international food and energy prices allows for the control of imported inflation, the

\footnotetext{
18 See Driscoll and Kraay (1998).

${ }^{19}$ Carrière-Swallow and others (2016) and Caselli and Roitman (2016) also use the nominal effective exchange rate to estimate exchange-rate pass-through.
} 
inclusion of past inflation allows for the control of inflationary inertia, while the inclusion of the GDP gap allows for the control of inflationary pressures generated by excess demand, in line with the conventional approach. Alternatively, the GDP gap could be used to control for the distributive conflict, given the absence of information regarding unit labour costs and unemployment rates. In this study, the GDP gap is proxied by the cyclical component of GDP, calculated by means of a Hodrick-Prescott filter. Lastly, fixed effects for each country are included to control for their specific, structural characteristics.

The sample period runs from 1994 to 2016 , on a quarterly basis. The panel consists of 22 countries, primarily in Latin America and Eastern Europe (see table 1). Fifteen of these 22 countries have already implemented inflation-targeting regimes. ${ }^{20}$

Table 1

Countries included in analysis

\begin{tabular}{lll}
\hline Argentina & India & Romania \\
\hline Bolivia (Plurinational State of) & Indonesia & Russian Federation \\
\hline Brazil & Malaysia & South Africa \\
\hline Bulgaria & Mexico & Thailand \\
\hline Chile & Philippines & Turkey \\
\hline Colombia & Paraguay & Uruguay \\
\hline Croatia & Peru & \\
\hline Hungary & Poland & \\
\hline
\end{tabular}

Source: Prepared by the authors.

Note: Based on the International Monetary Fund classification of emerging and developing countries (2018).

The data sample includes episodes of sharp devaluation and/or hyperinflation (see table 2). Observations in which quarterly changes in the NEER and CPI are above 100\% were excluded from the sample, together with the three subsequent observations which affect one-year cumulative inflation. While these observations are unlikely to pertain to customary wage negotiations and/or price-fixing, their inclusion as part of the sample tends to distort estimates. This treatment of the data is similar to that carried out by Caselli and Roitman (2016) and Fischer, Sahay and Vegh (2002).

Table 2

Descriptive statistics for panel data

\begin{tabular}{lccccc}
\hline Variable & Observations & Mean & Standard deviation & Minimum & Maximum \\
\hline$\Delta \mathrm{n} \mid \mathrm{PC}$ & 2318 & 0.040 & 0.105 & -0.038 & 2.144 \\
\hline$\Delta \mathrm{nTCNE}$ & 2334 & 0.028 & 0.121 & -0.379 & 1.753 \\
\hline$\Delta \mathrm{nPal}$ & 2266 & 0.003 & 0.059 & -0.304 & 0.163 \\
\hline$\Delta \mathrm{n} \mathrm{nPer}$ & 2178 & 0.010 & 0.129 & -0.627 & 0.262 \\
\hline $\ln \left(\mathrm{y} / \mathrm{y}^{*}\right)$ & 1935 & 1.010 & 0.033 & 0.728 & 1.248 \\
\hline
\end{tabular}

Source: Prepared by the authors on the basis of data from the International Monetary Fund (IMF), the Economic Commission for Latin America and the Caribbean (ECLAC), Bruegel and official information from the countries.

Note: $\ln \left(y / y^{*}\right)$ is the cyclical component of the product, from which the gap is approximated.

Estimates carried out in 12-year rolling windows confirm the results found in the literature: exchangerate pass-through to consumer prices declined from 0.52 in the period 1994-2005 to 0.16 in the period 2005-2016 (see figure 1). Estimates for different time horizons also show that the largest falloff in the exchange-rate pass-through is focused on the second and third quarters following a devaluation and that the exchange-rate effect stabilizes between the third and fourth quarters (see figure 2). This would suggest that the use of a four-quarter timespan is appropriate to measure the total effect.

20 Of these 15 countries, 13 had inflation-targeting regimes in place for over half of the 2001-2016 period: Brazil, Chile, Colombia, Hungary, Indonesia, Mexico, Peru, Philippines, Poland, Romania, South Africa, Thailand and Turkey. India adopted an inflation-targeting regime in 2016. Argentina an inflation-targeting regime in 2017 and suspended it in 2018. 
Figure 1

Exchange-rate pass-through in peripheral countries, by rolling time windows (Percentages)

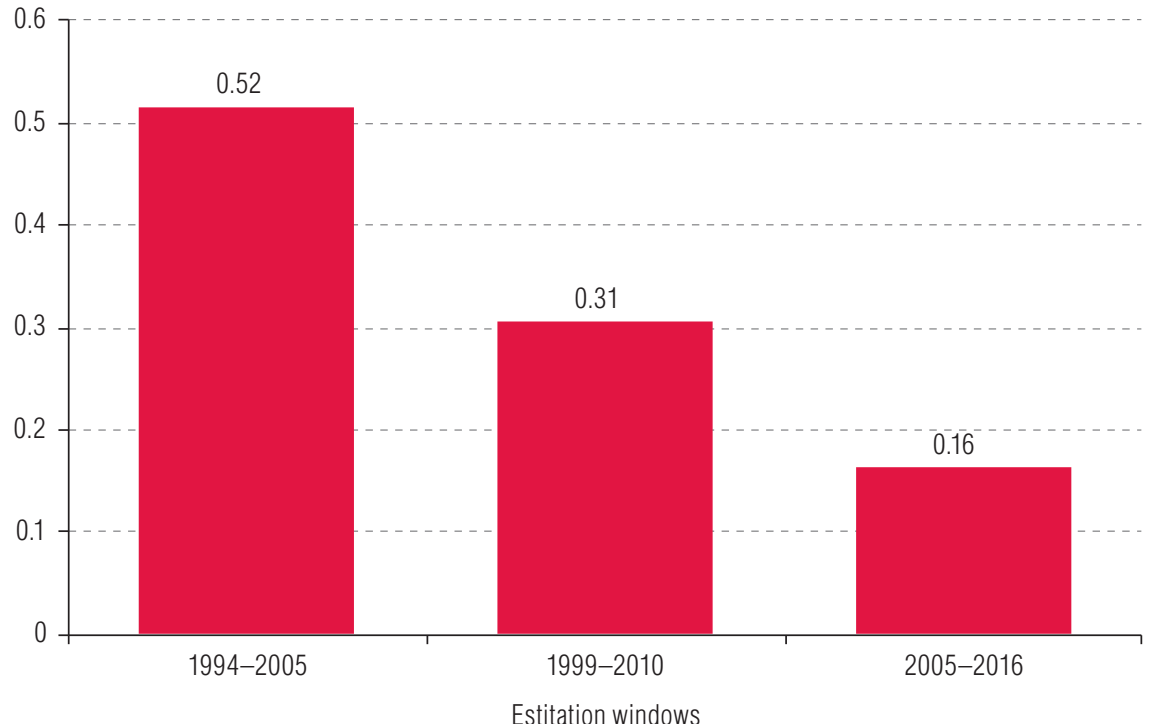

Source: Prepared by the authors.

Note: Cumulative response of consumer prices one year after a $1 \%$ increase in the nominal effective exchange rate. The following countries are included in the estimates: Argentina, Bolivia (Plurinational State of), Brazil, Bulgaria, Chile, Colombia, Croatia, Hungary, India, Indonesia, Malaysia, Mexico, Paraguay, Peru, Philippines, Poland, Romania, Russian Federation, South Africa, Thailand, Turkey and Uruguay.

Figure 2

Exchange-rate pass-through in peripheral countries, for different timespans (Percentages)

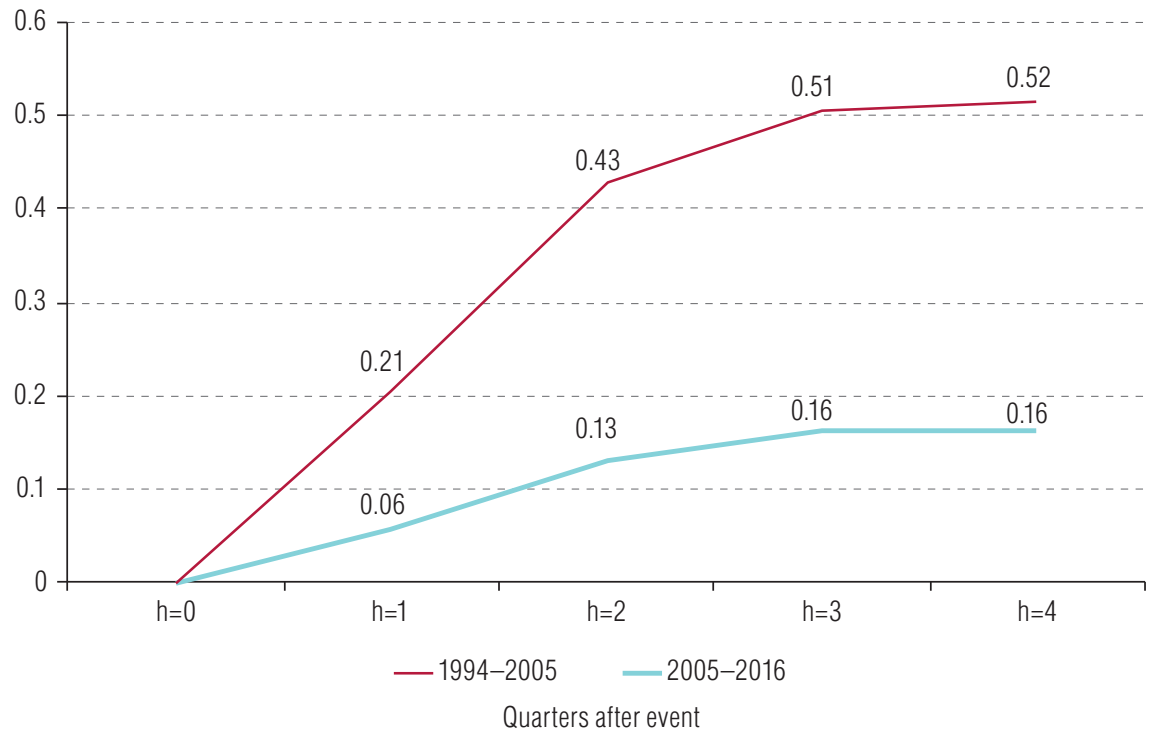

Source: Prepared by the authors.

Note: Cumulative response of consumer prices one, two, three and four quarters after a $1 \%$ increase in the nominal effective exchange rate. The following countries are included in the estimates: Argentina, Bolivia (Plurinational State of), Brazil, Bulgaria, Chile, Colombia, Croatia, Hungary, India, Indonesia, Malaysia, Mexico, Paraguay, Peru, Philippines, Poland, Romania, Russian Federation, South Africa, Thailand, Turkey and Uruguay. 
Estimates by region show that the decline in exchange-rate pass-through was widespread. Exchange-rate pass-through declined most steeply in Eastern Europe, from 0.86 to 0.17 between 1994-2005 and 2005-2016, and less steeply in Latin America from 0.34 to 0.18. Asian countries included in the study show the lowest exchange-rate pass-through in recent years (see figure 3).

\section{Figure 3}

Exchange rate pass-through by region

(Percentages)

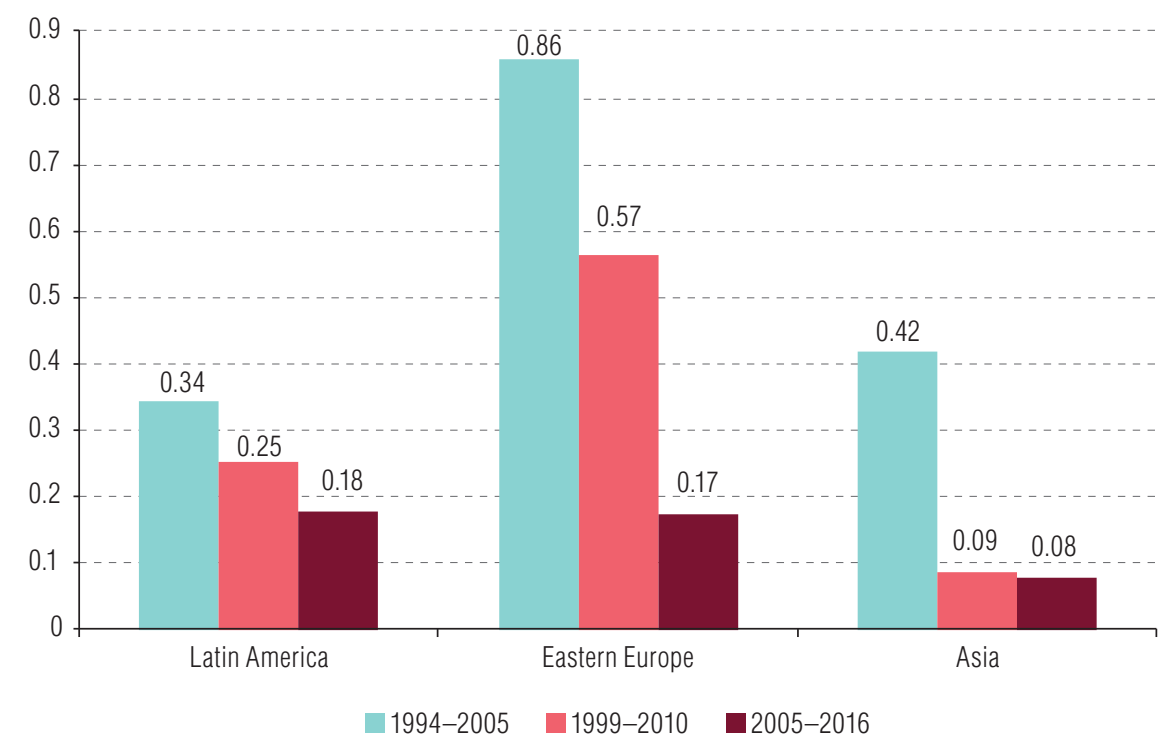

Source: Prepared by the authors.

Note: Cumulative response of consumer prices one year after a 1\% increase in the nominal effective exchange rate. Latin America includes: Argentina, Bolivia (Plurinational State of), Brazil, Chile, Colombia, Mexico, Paraguay, Peru and Uruguay; Eastern Europe includes: Bulgaria, Croatia, Hungary, Poland, Romania, Russian Federation and Turkey; Asia includes: Philippines, India, Indonesia, Malaysia and Thailand.

In order to determine the extent to which the decline in exchange-rate pass-through can be attributed to greater central bank credibility, estimates were made for two groups of countries: those that had adopted inflation-targeting regimes for a prolonged period ${ }^{21}$ and those that had not or had recently implemented such regimes. The results indicate two things. First, exchange-rate pass-through falls in both types of countries (i.e. those that apply inflation-targeting regimes and those that do not). This may imply that the decline observed is the result of a broader, global process and not necessarily linked to increased central bank credibility. Second, the estimates show that the reduction in exchange-rate pass-through was greater in countries with inflation-targeting regimes in place (see figure 4). While this outcome suggests that the implementation of inflation-targeting regimes may have helped to reduce pass-through more deeply, it could also reveal that the effects of other potential determinants (such as trade liberalization or weaker labour regulation) were more strongly felt in this second group.

\footnotetext{
21 These are countries where inflation-targeting regimes were in place for more than half of the last window (2005-2016), meaning it was implemented in or prior to 2010. They are: Brazil, Chile, Colombia, Hungary, Indonesia, Mexico, Peru, Philippines, Poland, Romania, South Africa, Thailand and Turkey.
} 
Figure 4

Exchange-rate pass-through, by monetary regime in peripheral countries

(Percentages)

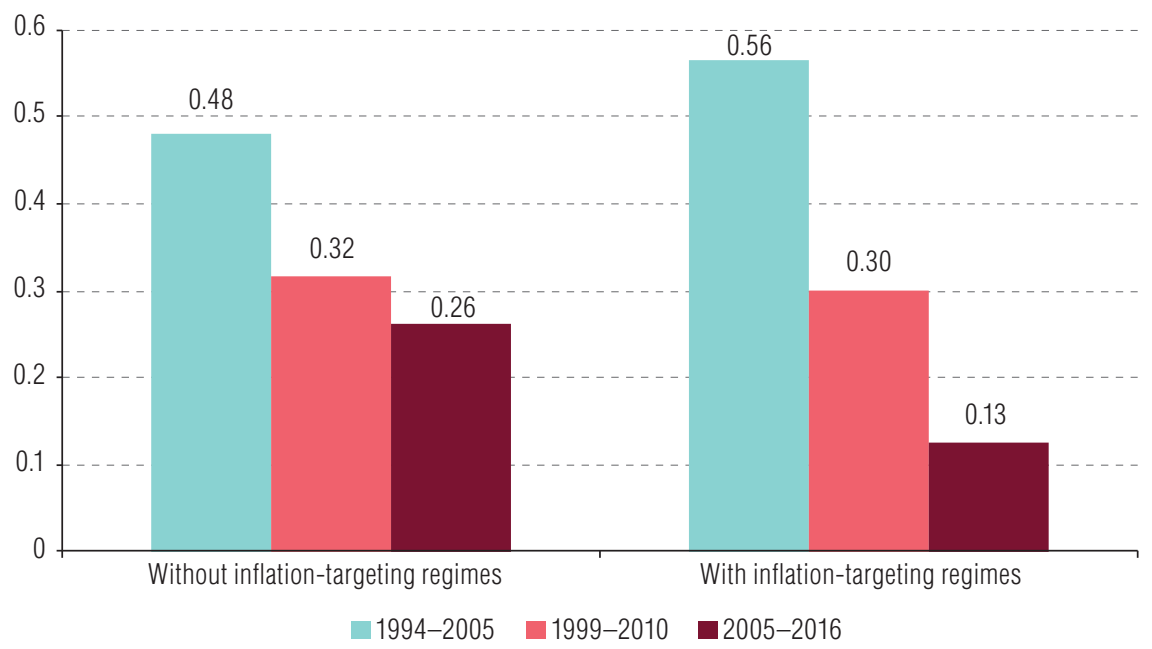

Source: Prepared by the authors.

Note: Cumulative response of consumer prices one year after a 1\% increase in the nominal effective exchange rate. Countries with inflation-targeting regimes (implemented in or prior to 2010) include: Brazil, Chile, Colombia, Hungary, Indonesia, Mexico, Peru, the Philippines, Poland, Romania, South Africa, Thailand and Turkey. Countries without inflation-targeting regimes (or with regimes implemented since 2011) include: Argentina, Bolivia (Plurinational State of), Bulgaria, Croatia, India, Malaysia, Paraguay, Russian Federation and Uruguay.

\section{Measurement of the first-round effect}

Once the total exchange-rate pass-through has been estimated, the question arises as to what extent the decline observed in recent decades was owed to the first-round effect, linked to the prices of tradable products, or the second-round effect, linked to non-tradables. It is therefore necessary to estimate the first-round effect separately. One benchmark indicator typically used in the literature for the first-round effect is the share of imported products in the household consumption basket. ${ }^{22}$

Input-output tables are used to measure the strength of first-round effects (Burstein, Eichenbaum and Rebelo, 2005; Carrière-Swallow and others, 2016; Gopinath, 2015), based Carrière-Swallow and others (2016), using data from the Eora multi-region input-output tables (Lenzen and others, 2012 and 2013).

The share of imports of final goods is obtained by calculating the ratio of consumption imports to total consumption. The share of intermediate imports is calculated by multiplying local production intended for private consumption by the share of intermediate imports per sector. The sum of all sectors is then calculated, and this is divided by total private consumption.

The import content of private consumption increased in the Latin American and Eastern European countries included in the panel (see figure 5). These results are in line with the growing importance of global value chains, which raised trade flows both into and from these countries. In Asian countries, however, this content remained stable.

Figure 6 shows that the recent decline in pass-through contrasts with the increase in the share of imported products. In Latin America and Eastern Europe, pass-through coefficients tend to move closer to the import content of household consumption. The data do not provide sufficient evidence to show

\footnotetext{
22 This benchmark assumes that the exchange-rate pass-through to the price of imported goods and services is complete and it excludes export goods that are part of the household consumption basket. Although empirical evidence shows that pass-through to imported products tends to be complete, in some cases it can be partial, as is typically the case in more differentiated goods (Campa and Goldberg, 2005).
} 
that there was no weakening of the first-round effect in these countries; however, they do suggest that the recent decline in pass-through is more closely related the second-round effects, i.e. to the price dynamics of non-tradable goods and services. To assess the extent to which the weakening of labour market institutions played a part in the lower second-round effect, in the following section we estimate a proxy for wage resistance.

\section{Figure 5}

Import content of private consumption, by region

(Percentages)

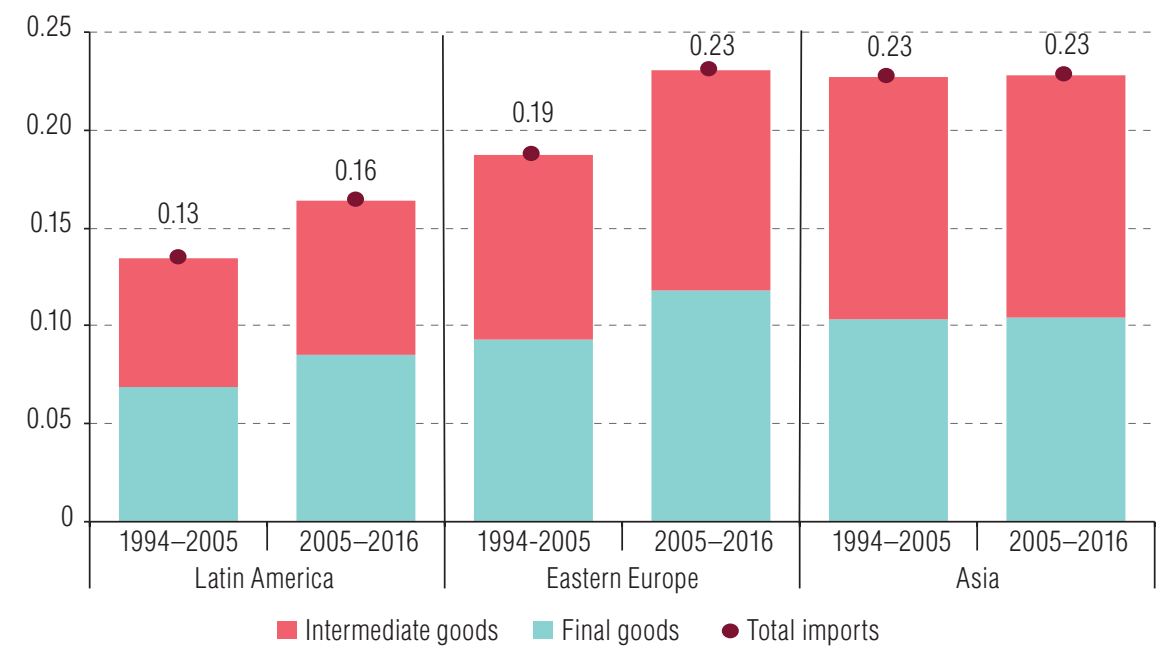

Source: Prepared by the authors, on the basis of M. Lenzen and others, "Building EORA: a global multi-region input-output database at high country and sector resolution", Economic Systems Research, vol. 25, № 1, Abingdon, Taylor \& Francis, 2013; and "Mapping the structure of the world economy", Environmental Science \& Technology, vol. 46, № 15, Washington, D.C., American Chemical Society, 2012.

Note: Shows the share of intermediate, final and total imported goods in private consumption. Latin America includes: Argentina, Bolivia (Plurinational State of), Brazil, Chile, Colombia, Mexico, Paraguay, Peru and Uruguay; Eastern Europe includes: Bulgaria, Croatia, Hungary, Poland, Romania, Russian Federation and Turkey; Asia includes: Philippines, India, Indonesia, Malaysia and Thailand.

Figure 6

Exchange-rate pass-through and import content of private consumption, by region (Percentages)

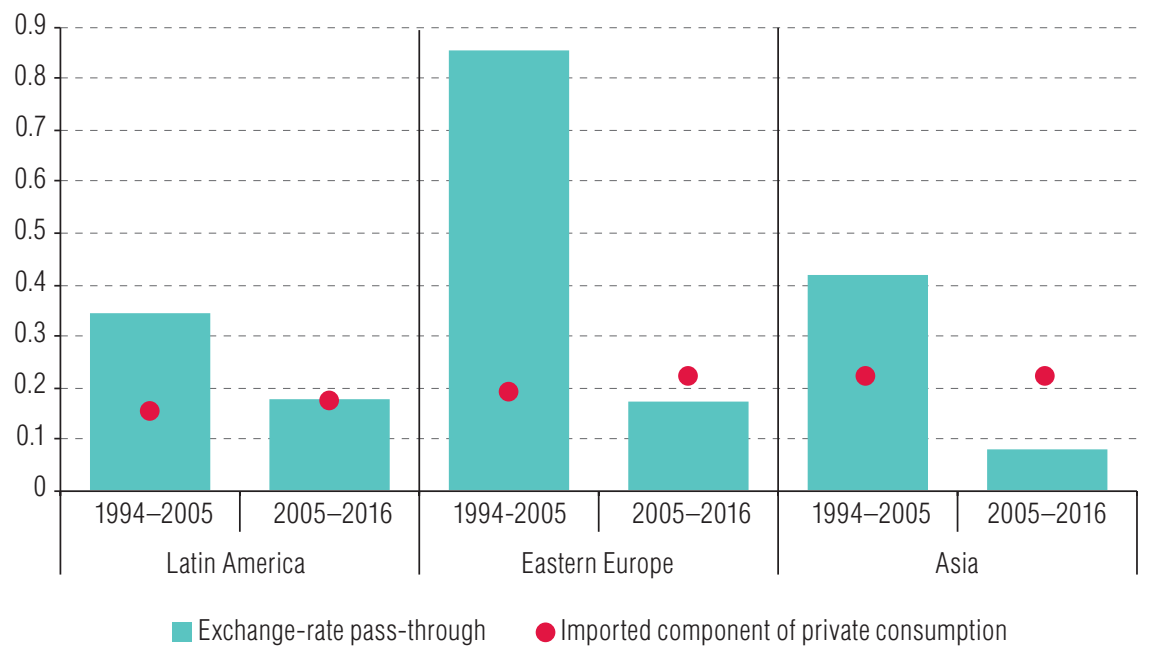

Source: Prepared by the authors.

Note: The solid bars show the cumulative response of consumer prices one year after a $1 \%$ increase in the nominal effective exchange rate. The plotted points show the share of intermediate and final imported goods in private consumption. Latin America includes: Argentina, Bolivia (Plurinational State of), Brazil, Chile, Colombia, Mexico, Paraguay, Peru and Uruguay; Eastern Europe includes: Bulgaria, Croatia, Hungary, Poland, Romania, Russian Federation and Turkey; Asia includes: Philippines, India, Indonesia, Malaysia and Thailand. 


\section{Labour market institutions and wage resistance}

In recent years, labour market institutions have been eroded globally (Berg, 2015). The expansion of the global work force resulting from the inclusion of China, India as well as the Russian Federation and the countries of the former Soviet Union to the global economy created upward pressure on unemployment and fostered labour flexibilization in virtually all countries, leading to worldwide intensification of wage discipline.

Greater labour flexibility shows up in various ways, including the promotion of non-standard employment (fixed-term employment or extension of probationary periods), reduction of job security (shortening of notice periods and reduction of severance pay), the decentralization of collective bargaining (elimination or suspension of national collective agreements), weakening of and interventions in collective bargaining (suspension of existing agreements and limitation of the duration of agreements) and weakening of trade unions (facilitating the conditions for non-union employee representatives to conclude collective agreements) (United Nations, 2016, pp. 7-8). Figure 7 shows the declining trend in collective bargaining coverage in a number of countries of the Organization for Economic Cooperation and Development (OECD).

Figure 7

Collective bargaining coverage

(Percentages)

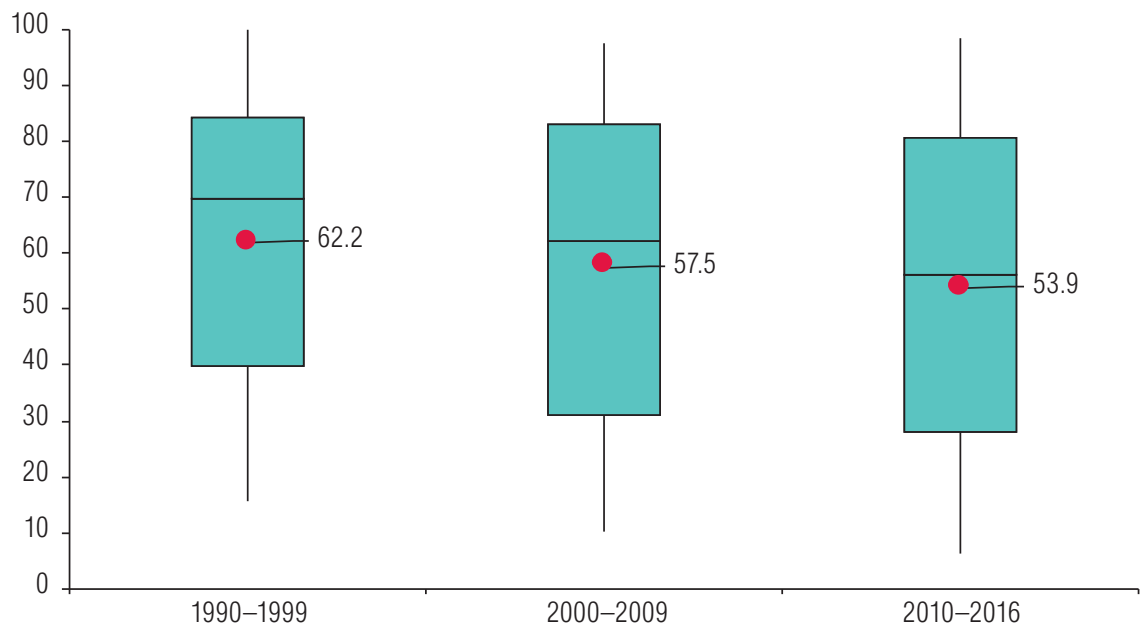

Source: Prepared by the authors, on the basis of data from the Organization for Economic Cooperation and Development (OECD).

Note: The rectangles and the central indicator denote the interquartile range and the median of the distribution, respectively. The plotted points correspond to the mean for each period. Sample countries include: Australia, Canada, Czechia, Denmark, Finland, France, Germany, Greece, Hungary, Iceland, Japan, Luxembourg, Netherlands, New Zealand, Norway, Portugal, Republic of Korea, Slovenia, Spain, Sweden, Switzerland, Turkey, United Kingdom and United States.

The weakening of labour's bargaining power is also related to financialization, in two possible ways (Stockhammer, 2013): (i) by increasing possibilities for investing in financial assets and abroad, thus reducing the incentives to invest in real domestic assets and inducing "short-termism"; and (ii) by empowering shareholders relative to workers, through changes in corporate governance as well as by the development of capital markets, which places emphasis on dividend payments and encourages cost-cutting strategies (Lazonick and O'Sullivan 2000).

Using trade openness as a proxy for the magnitude of globalization and the size of external assets and liabilities over GDP as a proxy for the spread of financialization, in line with Stockhammer (2013), it can be seen that both indicators - which are negatively associated with workers' bargaining power- 
have trended upwards in recent years. The increase was more pronounced in countries that implemented inflation-targeting regimes, where the exchange-rate pass-through declined the most (see figures 8 and 9).

Figure 8

Globalization indicator

(Index: 1994-2005 window=100)

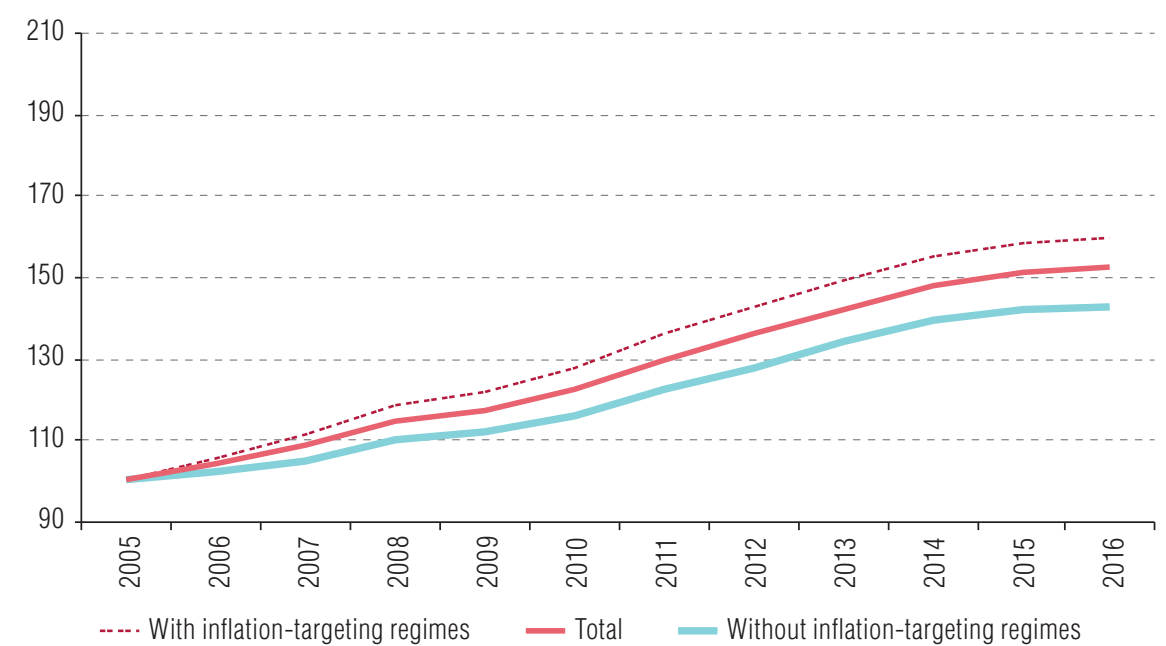

Source: Prepared by the authors, on the basis of information from International Monetary Fund (IMF) and the World Bank.

Note: Series correspond to indices for the 12-year moving average since 1994. The gross domestic product (GDP) used as the denominator of the financialization indicator is adjusted for purchasing power parity (PPP). Countries with inflation-targeting regimes (implemented in or prior to 2010) include: Brazil, Chile, Colombia, Hungary, Indonesia, Mexico, Peru, the Philippines, Poland, Romania, South Africa, Thailand and Turkey. Countries without inflation-targeting regimes (or with regimes implemented since 2011) include: Argentina, Bolivia (Plurinational State of), Bulgaria, Croatia, India, Malaysia, Paraguay, Russian Federation and Uruguay.

\section{Figure 9}

Financialization indicator

(Index: 1994-2005 window=100)

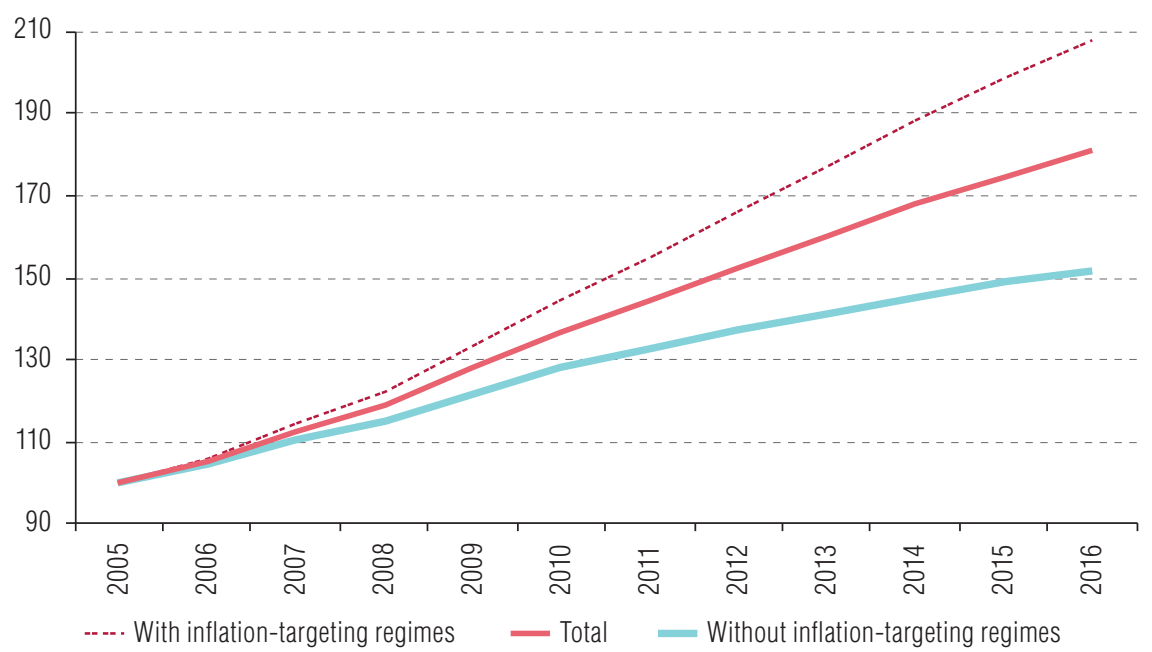

Source: Prepared by the authors, on the basis of information from International Monetary Fund (IMF) and the World Bank.

Note: Series correspond to indices for the 12-year moving average since 1994. The gross domestic product (GDP) used as the denominator of the financialization indicator is adjusted for purchasing power parity (PPP). Countries with inflation-targeting regimes (implemented in or prior to 2010) include: Brazil, Chile, Colombia, Hungary, Indonesia, Mexico, Peru, the Philippines, Poland, Romania, South Africa, Thailand and Turkey. Countries without inflation-targeting regimes (or with regimes implemented since 2011) include: Argentina, Bolivia (Plurinational State of), Bulgaria, Croatia, India, Malaysia, Paraguay, Russian Federation and Uruguay. 
The trade openness (globalization) indicator is particularly relevant in linking the decline in exchangerate pass-through with the weakening of labour market institutions if one considers that, from the point of view of pricing, trade liberalization must have increased competition between domestic and foreign firms (Benigno and Faia, 2016).

In any inflationary process, workers' bargaining power is reflected in their ability to mitigate or offset their loss of real income over time. This aspect of the distributive conflict is fundamental for determining the intensity of the second-round effect caused by an increase in the exchange rate (see section II).

To assess changes in wage resistance in recent years, expression (4.1) was estimated using the local projection method and quarterly series of nominal wages using rolling windows (see annex A2) for a subset of 10 countries for which sufficient data are available. ${ }^{23,24}$

$$
\ln w_{i, t+h-1}-\ln w_{i, t-1}=\alpha_{0}+\sum_{j=1}^{j}\left(\alpha_{1, j}^{h} p_{i, t-j}\right)+\alpha_{2}^{h} p r_{i, t}+\alpha_{3}^{h} u_{i, t}+v_{i, t}
$$

Where $w$ is the nominal wage, $p$ is the logarithmic difference of the consumer price index, $p r$ is the logarithmic difference of labour productivity, $u$ is the unemployment rate, $v$ is an error term, $h$ is the projection timespan, $i$ denotes each of the countries included in the panel and $j$ the number of lags. The number of lags considered for the consumer price index is two $(j=2)$ and the selected projection timespan is four quarters $(h=4)$. We are interested in $\alpha_{1, j=1}^{h=4}$, a parameter that reflects the extent of the cumulative response of nominal wages one year after an increase in consumer prices, which we use as a proxy for wage resistance.

Unemployment rates and labour productivity data were estimated as annual series by means of a Hodrick-Prescott filter (insufficiency of quarterly data did not allow for a higher frequency). Nominal wages were obtained from international organizations and national agencies (see annex A2).

The results show a reduction in wage resistance in recent years, which is consistent with the evidence of the weakening of labour market institutions and the decline in the exchange-rate pass-through for the same group of countries (see figure 10). These findings suggest that lower wage resistance to past inflation may have been a significant factor in the decline in pass-through.

The fall in wage resistance was most marked in countries with inflation-targeting regimes (see figure 11). This suggests that the greater decline in exchange-rate pass-through in these countries may be tied to lower wage resistance stemming from changes in labour market institutions. This result is also consistent with the steeper rise in the globalization and financialization indicators - which are negatively associated with workers' bargaining power - in the group of countries with inflation-targeting regimes. This hypothesis is empirically tested in the following section.

\footnotetext{
${ }^{23}$ Countries with quarterly nominal wages series covering a period of 20 years or more.

24 The work of Vogel and others (2009) is a noteworthy antecedent. Vogel and others (2009) estimate the resistance of real wages to changes in the terms of trade in the Group of Seven (G7) countries to analyse the second-round effects of inflation caused by the sharp rise in commodity prices that took place during the first half of 2008. An autoregressive distributed lag equation was used for the estimate, which suggests that real wage resistance as captured by the corresponding parameter declined after the 1970s.
} 


\section{Figure 10}

Exchange-rate pass-through, wage resistance and import content of private consumption (Percentages)

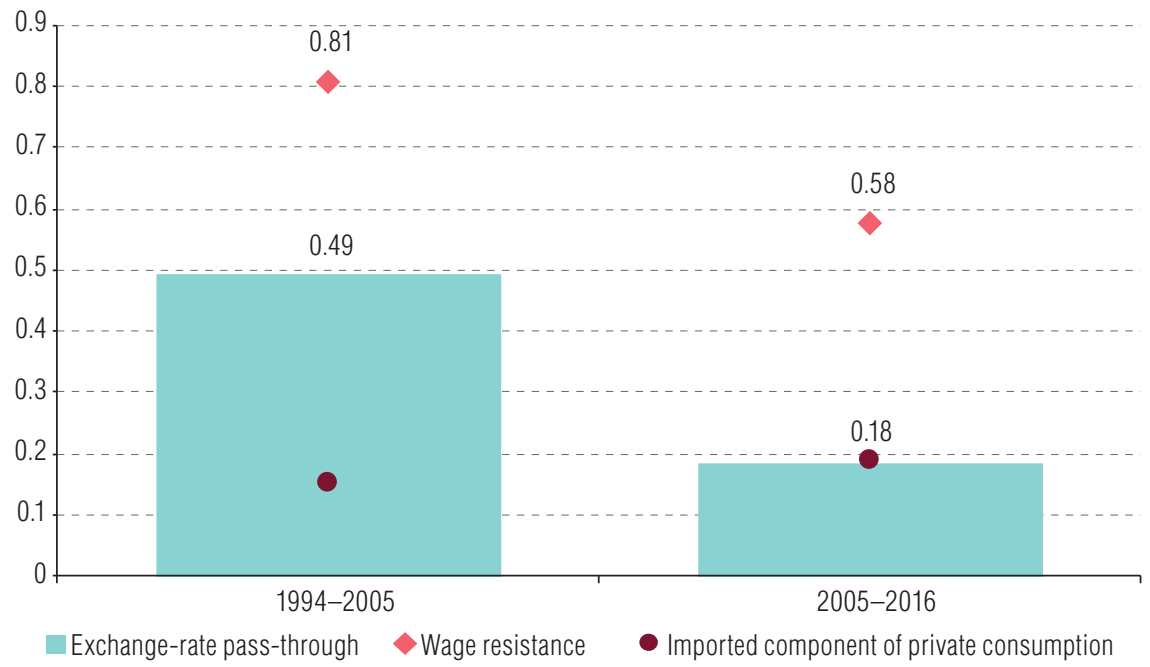

Source: Prepared by the authors.

Note: The exchange-rate pass-through reflects the cumulative response of consumer prices one year after a $1 \%$ increase in the nominal effective exchange rate. The import content indicates the share of intermediate and final imported goods in private consumption. Wage resistance indicates the cumulative response of nominal wages one year after a $1 \%$ increase in consumer prices. Country fixed effects are included in the estimations of exchange-rate pass-through and wage resistance. Countries included in the estimates are: Argentina, Brazil, Chile, Colombia, Croatia, Hungary, Poland, Romania, Russian Federation and Uruguay.

\section{Figure 11}

Exchange-rate pass-through, wage resistance and import content of private consumption, by monetary regime

(Percentages)

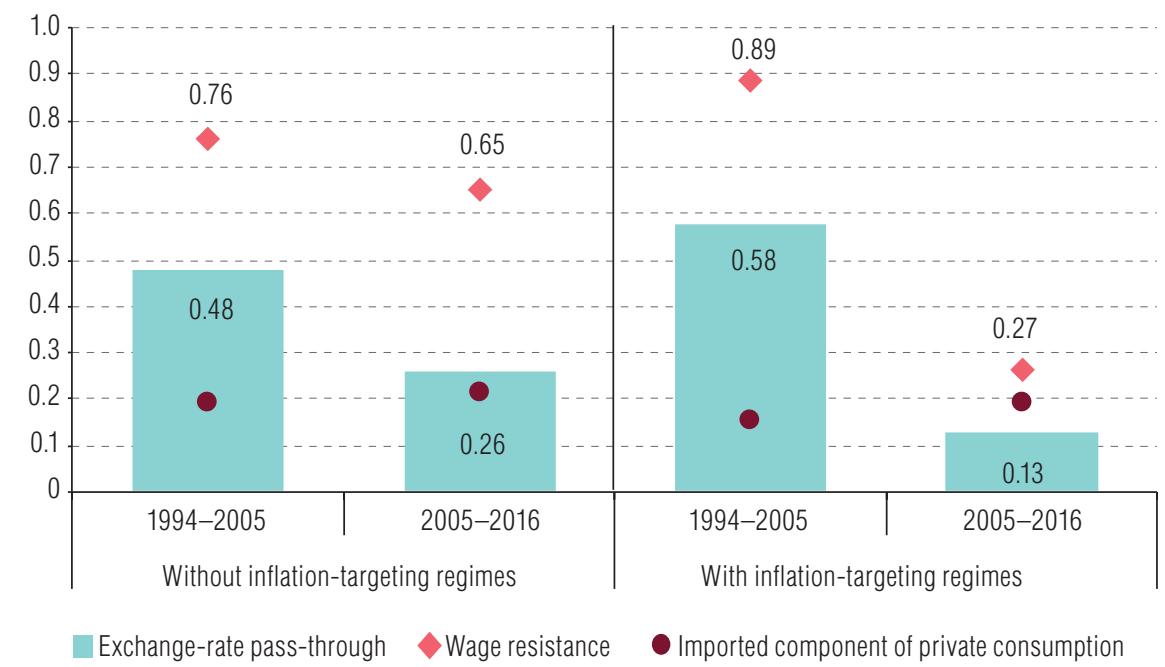

Source: Prepared by the authors.

Note: The exchange-rate pass-through reflects the cumulative response of consumer prices one year after a $1 \%$ increase in the nominal effective exchange rate. The import content indicates the share of intermediate and final imported goods in private consumption. Wage resistance indicates the cumulative response of nominal wages one year after a $1 \%$ increase in consumer prices. Countries without inflation-targeting regimes include: Argentina, Croatia, Russian Federation and Uruguay. Countries with inflation-targeting regimes include: Brazil, Chile, Colombia, Hungary, Poland and Romania. Country fixed effects are included in the estimations of exchange-rate pass-through and wage resistance. 


\section{The link between wage resistance and exchange-rate pass-through}

A similar strategy to that applied by Carrière-Swallow and others (2016) and Choudhri and Hakura (2006) was used to assess the determinants of exchange-rate pass-through in two steps. First, we estimated exchange-rate pass-through and wage resistance coefficients by equations (3.1) and (4.1), respectively, for each country, using 12-year rolling windows. Rolling windows begin in the first quarter of each year, starting in 1994. This means that we have used 12 windows, the first for 1994-2005, the second for 1995-2006, and the last for 2005-2016.

Second, we ran a regression between exchange rate pass-through coefficients and wage resistance coefficients obtained in the first (5.1 below). The globalization indicator (see section IV) and other variables which, according to the literature, may affect exchange-rate pass-through, such as the mean and standard deviation of inflation (inflation volatility) and the mean and standard deviation of exchange rate variation (exchange rate volatility), were also included as explanatory variables. ${ }^{25}$ The latter are also calculated for the same periods used for exchange rate pass-through and wage resistance. Estimates are conducted for a subset of 10 countries for which quarterly nominal wage data are available (see annex A2).

$$
\beta_{1, i, \tau}^{h=4}=\delta \chi_{i, \tau}+\varsigma_{\tau}+\epsilon_{i, \tau}
$$

Where $\beta{ }_{1, i, \tau}^{h=4}$ are the pass-through coefficients, and $\chi_{i, \tau}$ and $\delta$ denote the explanatory variables (the mean and standard deviation of inflation and of the rate of variation of the nominal exchange rate, the globalization indicator and wage resistance) and their respective coefficients. The observations pertain to each time window $(\tau)$ and country in the sample $(i)$. The specification includes time fixed effects $\left(\varsigma_{\tau}\right)$.

The different estimates of equation (5.1) show that each of the explanatory variables is significant when included individually (see table 3, columns 1-6). When all explanatory variables are included together and the results are controlled for time fixed effects, average depreciation and the wage resistance indicator are significant (see table 3, column 7). When country fixed effects are also included to control for each country's structural characteristics, exchange rate volatility, average inflation, the globalization indicator and wage resistance are significant (see table 3, column 8). Similar results are obtained and presented in annex $\mathrm{A} 3$, based on the bilateral nominal exchange rate instead of the effective nominal exchange rate.

The coefficients obtained for average depreciation, exchange-rate volatility and average inflation in the regressions where these variables are significant report a positive sign, as expected. This is also consistent with empirical literature: the greater the exchange-rate instability and the higher the starting level of inflation, the greater the pass-through coefficient.

Wage resistance is significant in the two regressions that include all variables (with and without country fixed effects) and the sign of the related coefficient is positive, in line with our working hypothesis: the lower the capacity (bargaining power) for a recovery in wages after a devaluation, the less intense the second-round pass-through will be. Additionally, the globalization indicator is significant in the regression that includes country fixed effects and its coefficient has a negative sign. This result can be interpreted as follows: as trade openness increases, there is more indirect competition between workers at the global level, the pressure for flexibilization of the local labour market increases, wage negotiating power decreases and second-round pass-through loses strength.

\footnotetext{
25 In the literature it is argued that as inflation and exchange-rate movements become more pronounced and more volatile, firms tend to adjust their prices more frequently and exchange-rate pass-through tends to increase.
} 
Table 3

Determinants of total pass-through of the nominal effective exchange rate

\begin{tabular}{|c|c|c|c|c|c|c|c|c|}
\hline Dependent variable: $\beta \beta_{1, i, \tau}^{h=4}$ & 1 & 2 & 3 & 4 & 5 & 6 & 7 & 8 \\
\hline \multirow[t]{2}{*}{ Average depreciation } & $11.423^{\text {***}}$ & & & & & & $11.594^{\star \star \star}$ & 1.344 \\
\hline & (1.58) & & & & & & (2.93) & (3.15) \\
\hline \multirow{2}{*}{$\begin{array}{l}\text { Nominal-effective-exchange- } \\
\text { rate volatility }\end{array}$} & & $2.384^{\star \star \star}$ & & & & & -0.435 & $2.235^{\star *}$ \\
\hline & & $(0.75)$ & & & & & $(0.74)$ & (1.02) \\
\hline \multirow[t]{2}{*}{ Average inflation } & & & $.710^{* \star *}$ & & & & 2.468 & $7.636^{\star \star *}$ \\
\hline & & & (1.16) & & & & $(2.37)$ & (2.65) \\
\hline \multirow[t]{2}{*}{ Inflation volatility } & & & & $4.752^{* \star \star}$ & & & -0.949 & -1.466 \\
\hline & & & & $(0.92)$ & & & (1.33) & (1.38) \\
\hline \multirow[t]{2}{*}{ Globalization indicator } & & & & & $.051^{\star \star \star}$ & & 0.132 & $-0.967^{\star \star \star}$ \\
\hline & & & & & $(0.37)$ & & $(0.10)$ & $(0.30)$ \\
\hline \multirow[t]{2}{*}{ Wage resistance } & & & & & & $0.072^{\star \star \star}$ & $0.079^{\star \star}$ & $0.100^{\star * *}$ \\
\hline & & & & & & $(0.03)$ & $(0.04)$ & $(0.04)$ \\
\hline Country fixed effects & No & No & No & No & No & No & No & Yes \\
\hline Time fixed effects & Yes & Yes & Yes & Yes & Yes & Yes & Yes & Yes \\
\hline Observations & 118 & 118 & 118 & 118 & 118 & 118 & 118 & 118 \\
\hline R-squared & 0.861 & 0.805 & 0.886 & 0.832 & 0.802 & 0.808 & 0.820 & 0.910 \\
\hline
\end{tabular}

Source: Prepared by the authors.

Note: The dependent variable is the estimated total pass-through to consumer prices for the time window $\tau$ and country $i$. The standard error is shown in parentheses. Significant at $1 \%\left(^{\star \star \star}\right)$, significant at $5 \%\left({ }^{\star \star}\right)$ and significant at $10 \%\left({ }^{\star}\right)$. Extreme observations where the exchange-rate pass-through to consumer prices was greater than 1 were excluded.

Overall, these results suggest that, given the level and volatility of inflation and the exchange rate, lower wage resistance (and greater trade openness) leads to lower exchange-rate pass-through to domestic consumer prices. The weakening of labour market institutions - when combined with these two variables - has global repercussions and may have played a significant role in explaining the decline in exchange rate pass-through observed in recent years.

\section{Conclusions}

This paper presents an alternative interpretation of the decline in the exchange-rate pass-through to consumer prices in recent decades in peripheral countries. Conventional wisdom claims that this decline was due to increased central bank credibility, which the literature typically ascribes to the establishment of formal inflation-targeting regimes and related institutional reforms, such as central bank independence, full mobility of international capital and floating exchange rates. From a structuralist standpoint, which views the distributive conflict as a fundamental factor in accounting for inflation, this paper has laid emphasis on other structural changes occurring in parallel with the establishment of inflation-targeting regimes, which have led to lower wage resistance, a key variable in explaining the intensity of exchange-rate pass-through. These changes include the weakening of labour market institutions and a decline in union density.

The empirical evidence gathered shows that exchange-rate pass-through declined in countries both with and without formal inflation-targeting regimes. This may imply that the decline was due to a broader, global process - not necessarily ascribable to greater credibility of monetary authoritiesthat could involve widespread trade liberalization, increasing financial deregulation or expansion of the global workforce. The data collected also indicate that the fall in exchange-rate pass-through was more significant in the countries with formal inflation-targeting regimes than in the rest of the countries in the sample. 
In keeping with conventional wisdom, this could suggest that, setting aside the likely incidence of the said global factors, the introduction of inflation-targeting regimes may have been a determining factor in the stronger decline in exchange-rate pass-through. However, a more detailed examination of the empirical evidence presented in sections IV and $\mathrm{V}$ reveals that: (i) the decline in wage resistance was more pronounced in countries with formal inflation-targeting regimes, and (ii) wage resistance is a statistically significant factor in explaining the strength of exchange-rate pass-through. From this, it could be inferred that the fall in pass-through was stronger in countries with formal inflation-targeting regimes because the reduction in wage resilience - and, presumably, the structural and institutional transformations that triggered that reduction - was greater in these countries, as opposed to enhanced central bank credibility.

These results, while perhaps not surprising, may still be of interest to those engaged in the comparative analysis of different capitalist institutional forms, such as proponents of the French regulation theory or the "varieties of capitalism" approach. ${ }^{26}$ The latter, for example, emphasizes the idea of institutional complementarities, which looks at how the functioning and performance of one institution can affect the functioning and performance of another. At times, conventional macroeconomic analysis appears to adopt a similar perspective, suggesting a combination of conditions that an economy must meet if the implementation of a formal inflation-targeting regime is to yield a low and stable inflation rate. These conditions usually include central bank independence, capital account liberalization, free floating exchange rates and self-imposed fiscal limits. ${ }^{27}$

An additional institutional prerequisite may be inferred from the evidence presented in this paper that is equally or more significant than the above - namely, labour market deregulation. ${ }^{28}$ This condition is rarely mentioned explicitly in the conventional literature, nor is it openly advocated by the enthusiasts of inflation-targeting regimes, even if it is perfectly consistent with the standard explanation. In fact, a more credible monetary authority may imply that workers' wage aspirations have been lined up with the official inflation target, whether spontaneously or by means of some sort of union representation. Going back to the interpretation of the decline in pass-through coefficients under inflation-targeting regimes, one further implication is that, in the event of an exchange-rate depreciation, workers offer minimal wage resistance, placidly accepting a real wage reduction. This may be conceivable if workers are certain that the only alternative to their acquiescence would be a contractionary monetary policy that would yield the same result (with regard to wages and the inflation rate) but with a much higher cost in terms of employment and activity levels. ${ }^{29}$ In short, the decline in exchange-rate pass-through - which, from a conventional perspective, is presented as an attribute of monetary credibility - is, in practice, a consequence of the weakening of labour institutions.

\footnotetext{
${ }^{26}$ For an application of the varieties of capitalism approach to Latin American countries, see Schneider (2009). For a critical review of this approach and its applicability in the region, see Aguirre and Lo Vuolo (2013). For an alternative perspective on Latin American economies based on regulatory theory, see Bizberg and Théret (2012).

27 See, for example, Fraga, Goldfajn and Minella (2003).

28 Similar reasoning can be found in Hall and Gingerich (2009).

29 This is referred to in the literature as the sacrifice ratio.
} 


\section{Bibliography}

Aguirre, J. and R. Lo Vuolo (2013), "Variedades de capitalismo: una aproximación al estudio comparado del capitalismo y sus aplicaciones para América Latina", Documentos de Trabajo CIEPP, No. 85, Buenos Aires, Interdisciplinary Centre for Public Research (CIEPP).

Arestis, P. and M. Sawyer (2005), "Aggregate demand, conflict and capacity in the inflationary process", Cambridge Journal of Economics, vol. 29, No. 6, Oxford, Oxford University Press.

Bailliu, J. and E. Fujii (2004), "Exchange rate pass-through and the inflation environment in industrialized countries: an empirical investigation", Bank of Canada Working Paper, No. 2004-21, Ottawa, Bank of Canada.

Bastian, E. and M. Setterfield (2017), "Nominal exchange rate shocks and inflation in an open economy: towards a structuralist inflation targeting agenda", NSSR Working Paper, No. 20/2017, New York, The New School for Social Research.

Benigno, P. and E. Faia (2016), "Globalization, pass-through, and inflation dynamics", International Journal of Central Banking, vol. 12, No. 4.

Berg, J. (ed.) (2015), Labour Markets, Institutions and Inequality: Building Just Societies in the 21st Century, Cheltenham, Edward Elgar/International Labour Organization (ILO).

Bhaduri, A. and S. Marglin (1990), "Unemployment and the real wage: the economic basis for contesting political ideologies", Cambridge Journal of Economics, vol. 14, No. 4, Oxford, Oxford University Press.

Bizberg, I. and B. Théret (2012), "La diversité des capitalismes latino-américains: les cas de l'Argentine, du Brésil et du Mexique", Revue de la Régulation, No. 11, Paris, Maison des Sciences de l'Homme Paris Nord.

Blecker, R. (2011), "Open economy models of distribution and growth", A Modern Guide to Keynesian Macroeconomics and Economic Policies, E. Hein and E. Stockhammer (eds.), Cheltenham, Edward Elgar. (1989), "International competition, income distribution and economic growth", Cambridge Journal of Economics, vol. 13, No. 3, Oxford, Oxford University Press.

Borensztein, E. and V. Queijo von Heideken (2016), "Exchange rate pass-through in South America: an overview", IDB Working Paper, No. 710, Washington, D.C., Inter-American Development Bank (IDB).

Burstein, A., M. Eichenbaum and S. Rebelo (2005), "Large devaluations and the real exchange rate", Journal of Political Economy, vol. 113, No. 4, Chicago, University of Chicago Press.

Calvo, G. and C. Reinhart (2002), "Fear of floating", The Quarterly Journal of Economics, vol. 117, No. 2, Oxford, Oxford University Press.

Campa, J. and L. Goldberg (2005), "Exchange rate pass-through into import prices", Review of Economics and Statistics, vol. 87, No. 4, Cambridge, Massachusetts, MIT Press.

Carlin, W. and D. Soskice (2006), Macroeconomics: Imperfections, Institutions, and Policies, Oxford, Oxford University Press.

Carrière-Swallow and others (2016), "Monetary policy credibility and exchange rate pass-through", IMF Working Paper, No. 16/240, Washington, D.C., International Monetary Fund (IMF).

Caselli, F. and A. Roitman (2016), "Non-linear exchange rate pass-through in emerging markets", IMF Working Paper, No. 16/1, Washington, D.C., International Monetary Fund.

Cassetti, M. (2003), "Bargaining power, effective demand and technical progress: a Kaleckian model of growth", Cambridge Journal of Economics, vol. 27, No. 3, Oxford, Oxford University Press.

Choudhri, E. and D. Hakura (2006), "Exchange rate pass-through to domestic prices: does the inflationary environment matter?", Journal of international Money and Finance, vol. 25, No. 4, Amsterdam, Elsevier. (2001), "Exchange rate pass-through to domestic prices: does the inflationary environment matter?", IMF Working Paper, No. 01/194, Washington, D.C., International Monetary Fund (IMF).

Cornwall, J. (1990), The Theory of Economic Breakdown, Oxford, Basil Blackwell.

Cornwall, J. and W. Cornwall (2001), Capitalist Development in the Twentieth Century, Cambridge, Cambridge University Press.

Devereux, M. and J. Yetman (2010), "Price adjustment and exchange rate pass-through", Journal of International Money and Finance, vol. 29, No. 1, Amsterdam, Elsevier.

Dornbusch, R. (1987), "Exchange rate and prices", American Economic Review, vol. 77, No. 1, Nashville, Tennessee, American Economic Association.

Driscoll, J. and A. Kraay (1998), "Consistent covariance matrix estimation with spatially dependent panel data", Review of Economics and Statistics, vol. 80, No. 4, Cambridge, Massachusetts, MIT Press. 
Dutt, A. (1987), "Alternative closures again: a comment on 'Growth, distribution and inflation'”, Cambridge Journal of Economics, vol. 11, No. 1, Oxford, Oxford University Press.

Dvoskin, A. and G. Feldman (2015), "Política cambiaria, distribución del ingreso y estructura productiva", Estructura productiva y politica macroeconómica: enfoques heterodoxos desde América Latina, A. Bárcena, A. Prado and M. Abeles (eds.), ECLAC Books, No. 138 (LC/G.2653-P), Santiago, Economic Comission for Latin America and the Caribbean (ECLAC).

Fischer, S., R. Sahay and C. Vegh (2002), "Modern hyper-and high inflations", NBER Working Paper, No. 8930, Cambridge, Massachusetts, National Bureau of Economic Research (NBER).

Fraga, A., I. Goldfajn and A. Minella (2003), "Inflation targeting in emerging market economies", NBER Working Paper, No. 10019, Cambridge, Massachusetts, National Bureau of Economic Research (NBER).

Frankel, J., D. Parsley and S. Wei (2012), "Slow pass-through around the world: a new import for developing countries?", Open Economies Review, vol. 23, No. 2, New York, Springer.

Freeman, R. (2006), "The great doubling: the challenge of the new global labor market" [online] https://www. researchgate.net/publication/237491969.

Frenkel, R. (1984), "Inflación, shocks y mark-up: Argentina 1975-1982", Ensayos Económicos, No. 30, Buenos Aires, Central Bank of Argentina.

Furtado, C. (1963), The Economic Growth of Brazil, Berkeley, University of California Press.

Gagnon, J. and J. Ihrig (2004), "Monetary policy and exchange rate pass-through", International Journal of Finance \& Economics, vol. 9, No. 4, Hoboken, Wiley.

Godley, W. and M. Lavoie (2007), Monetary Economics: An Integrated Approach to Credit, Money, Income, Production and Wealth, New York, Palgrave Macmillan.

Gopinath, G. (2015), "The international price system", NBER Working Paper, No. 21646, Cambridge, Massachusetts, National Bureau of Economic Research (NBER).

Hall, P. and D. Gingerich (2009), "Varieties of capitalism and institutional complementarities in the political economy: an empirical analysis", British Journal of Political Science, vol. 39, No. 3, Cambridge, Cambridge University Press.

Jordà, Ò. (2005), "Estimation and inference of impulse responses by local projections", American Economic Review, vol. 95, No. 1, Nashville, Tennessee, American Economic Association.

Kalecki, M. (1971), "Costs and prices", Selected Essays on the Dynamics of the Capitalist Economy 1933-1970, Cambridge, Cambridge University Press.

Krugman, P. (1987), "Pricing to market when the exchange rate changes," Real Financial Linkages Among Open Economies, S. Arndt and J. Richardson (eds.), Cambridge, Massachusetts, MIT Press.

Lavoie, M. (2014), Post-Keynesian Economics: New Foundations, Cheltenham, Edward Elgar.

Lazonick, W. and M. O'Sullivan (2000), "Maximizing shareholder value: a new ideology for corporate governance", Economy and Society, vol. 29, No. 1, Abingdon, Taylor \& Francis.

Lenzen, M. and others (2013), "Building EORA: a global multi-region input-output database at high country and sector resolution", Economic Systems Research, vol. 25, No. 1, Abingdon, Taylor \& Francis. (2012), "Mapping the structure of the world economy", Environmental Science \& Technology, vol. 46, No. 15, Washington, D.C., American Chemical Society.

Libman, E. (2018), "Asymmetric monetary and exchange-rate policies in Latin American countries that use inflation targeting", CEPAL Review, No. 125 (LC/PUB.2018/6-P), Santiago, Economic Commission for Latin America and the Caribbean (ECLAC).

Marston, R. (1990), "Pricing to market in Japanese manufacturing", Journal of International Economics, vol. 29, No. 3-4, Amsterdam, Elsevier.

Neville, J. and P. Kriesler (2008), "Expectations and unemployment", Keynes and Macroeconomics after 70 Years: Critical Assessments of The General Theory, L. Wray and M. Forstater (eds.), Cheltenham, Edward Elgar.

Noyola, J. (1956), "El desarrollo económico y la inflación en México y otros países latinoamericanos", Investigación Económica, vol. 16, No. 4, Mexico City, National Autonomous University of Mexico (UNAM).

Olivera, J. (1967), "Aspectos dinámicos de la inflación estructural”, Desarrollo Económico, vol. 7, No. 27, Buenos Aires, Institute of Economic and Social Development (IDES).

Perry, N. and N. Cline (2016), "What caused the great inflation moderation in the US? A post-Keynesian view", Review of Keynesian Economics, vol. 4, No. 4, Cheltenham, Edward Elgar. 
Rochon, L. and M. Setterfield (2007), "Interest rates, income distribution, and monetary policy dominance: post Keynesians and the 'fair rate' of interest", Journal of Post Keynesian Economics, vol. 30, No. 1, Abingdon, Taylor \& Francis.

Rowthorn, R. (1977), "Conflict, inflation and money", Cambridge Journal of Economics, vol. 1, No. 3, Oxford, Oxford University Press.

Sarantis, N. (1990), "Distribution and terms of trade dynamics, inflation, and growth", Journal of Post Keynesian Economics, vol. 13, No. 2, Abingdon, Taylor \& Francis.

Sawyer, M. (1982), Macro-Economics in Question: The Keynesian-Monetarist Orthodoxies and the Kaleckian Alternative, New York, M. E. Sharpe.

Schneider, B. (2009), "Hierarchical market economies and varieties of capitalism in Latin America", Journal of Latin American Studies, vol. 41, No. 3, Cambridge, Cambridge University Press.

Schönerwald da Silva, C. and M. Vernengo (2008), "The decline of the exchange rate pass-through in Brazil: explaining the 'fear of floating'”, International Journal of Political Economy, vol. 37, No. 4, Abingdon, Taylor \& Francis.

Setterfield, M. (2009), "Macroeconomics without the LM curve: an alternative view", Cambridge Journal of Economics, vol. 33, No. 2, Oxford, Oxford University Press.

(2006a), "Balancing the macroeconomic books on the backs of the workers: a simple analytical political economy model of contemporary US capitalism", International Journal of Political Economy, vol. 35, No. 3, Abingdon, Taylor \& Francis.

(2006b), "Is inflation targeting compatible with post Keynesian economics?", Journal of Post Keynesian Economics, vol. 28, No. 4, Abingdon, Taylor \& Francis.

Smithin, J. (1994), Controversies in Monetary Economics: Ideas, Issues, and Policy, Cheltenham, Edward Elgar.

Stockhammer, E. (2013), "Why have wage shares fallen? An analysis of the determinants of functional income distribution", Wage-led Growth. An Equitable Strategy for Economic Recovery, M. Lavoie and E. Stockhammer (eds.), London, Palgrave Macmillan/International Labour Organization (ILO).

Sunkel, O. (1958), "La inflación chilena: un enfoque heterodoxo", El Trimestre Económico, vol. 25, No. 4, Mexico City, Fondo de Cultura Económica.

Taylor, C. (1985), "Social theory as practice", Philosophy and the Human Sciences: Philosophical Papers 2, Cambridge, Cambridge University Press.

Taylor, J. (2000), "Low inflation, pass-through, and the pricing power of firms", European Economic Review, vol. 44, No. 7, Amsterdam, Elsevier.

Taylor, L. (2004), Reconstructing Macroeconomics: Structuralist Proposals and Critiques of the Mainstream, Cambridge, Massachusetts, Harvard University Press. (1991), Income Distribution, Inflation and Growth: Lectures on Structuralist Macroeconomic Theory, Cambridge, Massachusetts, MIT Press.

(1985), "A stagnationist model of economic growth", Cambridge Journal of Economics, vol. 9, No. 4, Oxford, Oxford University Press.

Teulings, C. and N. Zubanov (2014), "Is economic recovery a myth? Robust estimation of impulse responses", Journal of Applied Econometrics, vol. 29, No. 3, Hoboken, Wiley.

United Nations (2016), Report of the Independent Expert on the effects of foreign debt and other related international financial obligations of States on the full enjoyment of all human rights, particularly economic, social and cultural rights (A/HRC/34/57), New York, 27 December.

Vera, L. (2014), "The simple post-Keynesian monetary policy model: an open economy approach", Review of Political Economy, vol. 26, No. 4, Abingdon, Taylor \& Francis.

Vernengo, M. (2003), "Balance of payments constraint and inflation", Department of Economics Working Paper, № 2003-06, University of Utah.

Vogel, L. and others (2009), "Inflation responses to recent shocks: do G7 countries behave differently?", OECD Economics Department Working Paper, No. 689, Paris, Organization for Economic Cooperation and Development (OECD). 


\section{Annex A1}

\section{Obtaining the real equilibrium wage}

In line with Bastian and Setterfield (2017), the rates of growth of nominal wages and prices are defined taking only the income aspiration gap into consideration:

$$
\begin{aligned}
& \hat{w}_{t}=\mu_{1}\left(\left[\omega_{w 0}+\mu_{2} e_{t-1}^{R}\right]-\omega_{t-1}\right) \\
& \hat{p}_{t}=\varphi_{1}\left(\omega_{t-1}-\left[\omega_{f 0}-\varphi_{2} e_{t-1}^{R}\right]\right)
\end{aligned}
$$

The real equilibrium wage is obtained, provided that the real wage remains constant $\left(\hat{w}_{t}=\hat{p}_{t}\right)$ :

$$
\omega^{*}=\frac{\mu_{1} \omega_{w 0}+\varphi_{1} \omega_{f 0}+\left(\mu_{1} \mu_{2}-\varphi_{1} \varphi_{2}\right) e_{t}^{R}}{\mu_{1}+\varphi_{1}}
$$

Equation (A.3) is substituted into (A.2) to obtain the equilibrium inflation rate:

$$
p^{*}=\frac{\mu_{1} \varphi_{1}\left(\omega_{w 0}-\omega_{f 0}\right)+\left(\mu_{2}+\varphi_{2}\right) e_{t}^{R}}{\mu_{1}+\varphi_{1}}
$$

The variation rate of the nominal break-even exchange rate is obtained, assuming that the real exchange rate remains constant. This implies that the variation rate of the nominal exchange rate is equal to inflation, minus the variation rate of the prices of imported products in foreign currency $\left(\hat{e}=\hat{p}-\hat{p}^{f}\right)$.

$$
\begin{gathered}
\hat{e}^{*}=\frac{\mu_{1} \varphi_{1}\left[\left(\omega_{w 0}-\omega_{f 0}\right)+\left(\mu_{2}+\varphi_{2}\right) e_{t}^{R}\right]}{\mu_{1}+\varphi_{1}}-\hat{p}^{f} \\
\hat{e}^{*}=\frac{\mu_{1} \varphi_{1}\left(\omega_{w 0}-\omega_{f 0}\right)+\mu_{1} \varphi_{1}\left(\mu_{2}+\varphi_{2}\right) e_{t}^{R}-\hat{p}^{f}\left(\mu_{1}+\varphi_{1}\right)}{\mu_{1}+\varphi_{1}}
\end{gathered}
$$

We then solve for the real exchange rate:

$$
e_{t}^{R *}=\left[\hat{e}^{*}-\frac{\mu_{1} \varphi_{1}\left(\omega_{w 0}-\omega_{f 0}\right)+\hat{p}^{f}\left(\mu_{1}+\varphi_{1}\right)}{\mu_{1}+\varphi_{1}}\right] \frac{\mu_{1}+\varphi_{1}}{\mu_{1} \varphi_{1}\left(\mu_{2}+\varphi_{2}\right)}
$$

Finally, equation (A.6) is substituted into (A.3):

$$
\omega^{*}=\frac{\mu_{1} \omega_{w 0}+\varphi_{1} \omega_{f 0}+\left(\mu_{1} \mu_{2}-\varphi_{1} \varphi_{2}\right)\left[\frac{\left(\hat{e}+\hat{p}_{t}^{f}\right)\left(\mu_{1}+\varphi_{1}\right)-\mu_{1} \varphi_{1}\left(\omega_{w 0}-\omega_{f 0}\right)}{\mu_{1} \varphi_{1}\left(\mu_{2}+\varphi_{2}\right)}\right]}{\mu_{1}+\varphi_{1}}
$$




\section{Annex A2}

\section{Data sources}

Table A2.1

Data sources

\begin{tabular}{|c|c|c|c|}
\hline Variable & Frequency of publication & Methodology & Sources \\
\hline Consumer Price Index (CPI) & Monthly & Quarterly average & $\begin{array}{l}\text { International Monetary Fund (IMF), } \\
\text { national and provincial bodies }\end{array}$ \\
\hline Real effective exchange rate (REER) & Monthly & Quarterly average & Bruegel \\
\hline Commodity prices & Monthly & Quarterly average & IMF \\
\hline Gross domestic product (GDP) & Quarterly & Seasonal adjustment (X-12-ARIMA) & IMF, ECLAC, OECD and national bodies \\
\hline Unemployment & Yearly & Hodrick-Prescott filter & International Labour Organization (IL0) \\
\hline Productivity & Yearly & Hodrick-Prescott filter & ILO \\
\hline Trade flow over GDP & Yearly & - & World Bank \\
\hline External assets and liabilities & Yearly & - & IMF \\
\hline GDP (in purchasing power parity) & Yearly & - & IMF \\
\hline
\end{tabular}

Source: Prepared by the authors.

Table A2.2

Data sources for nominal wage series

\begin{tabular}{llll}
\hline Country & Period & Description & Source \\
\hline Argentina & $1995-2016$ & Average wage in the registered private sector & $\begin{array}{l}\text { Ministry of Labour, Employment and } \\
\text { Social Security }\end{array}$ \\
\hline Brazil & $1994-2016$ & Average private and public sector wage & $\begin{array}{l}\text { Brazilian Geographical and Statistical } \\
\text { Institute (IBGE) }\end{array}$ \\
\hline Chile & $1994-2016$ & Average wage & International Monetary Fund (IMF) \\
\hline Colombia & $1994-2016$ & Average wage (manufacturing industry & Bank of the Republic \\
\hline Croatia & $1994-2016$ & Net average wage & Croatian Bureau of Statistics \\
\hline Hungary & $1994-2016$ & Average wage & IMF \\
\hline Poland & $1994-2016$ & Average wage & IMF \\
\hline Romania & $1994-2016$ & Average wage & IMF \\
\hline Russian Federation & $1994-2016$ & Average wage & Federal State Statistics Service of the \\
& & Russian Federation
\end{tabular}

Source: Prepared by the authors. 


\section{Annex A3}

\section{Robustness control: estimation based on the bilateral nominal exchange rate}

The results based on the bilateral nominal exchange rate are similar to those obtained using the nominal effective exchange rate; a decrease was noted in all cases, with the largest declines in countries with inflation-targeting regimes (see figures A3.1 to A3.4 and table A3.1).

Figure A3.1

Exchange-rate pass-through in peripheral countries, by rolling windows (Percentages)

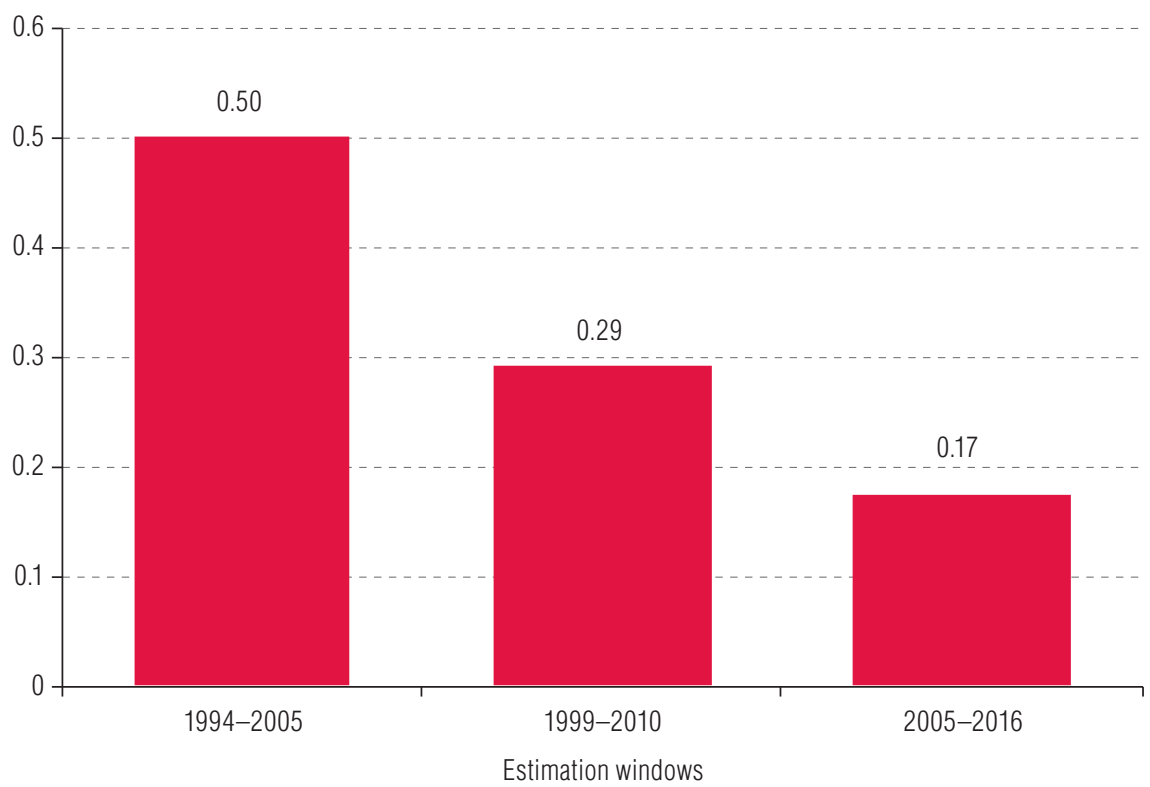

Source: Prepared by the authors.

Note: Cumulative response of consumer prices one year after a 1\% increase in the bilateral nominal exchange rate. The following countries are included in the estimates: Argentina, Bolivia (Plurinational State of), Brazil, Bulgaria, Chile, Colombia, Croatia, Hungary, India, Indonesia, Malaysia, Mexico, Paraguay, Peru, Philippines, Poland, Romania, Russian Federation, South Africa, Thailand, Turkey and Uruguay. 
Figure A3.2

Exchange-rate pass-through in peripheral countries, for different time horizons (Percentages)

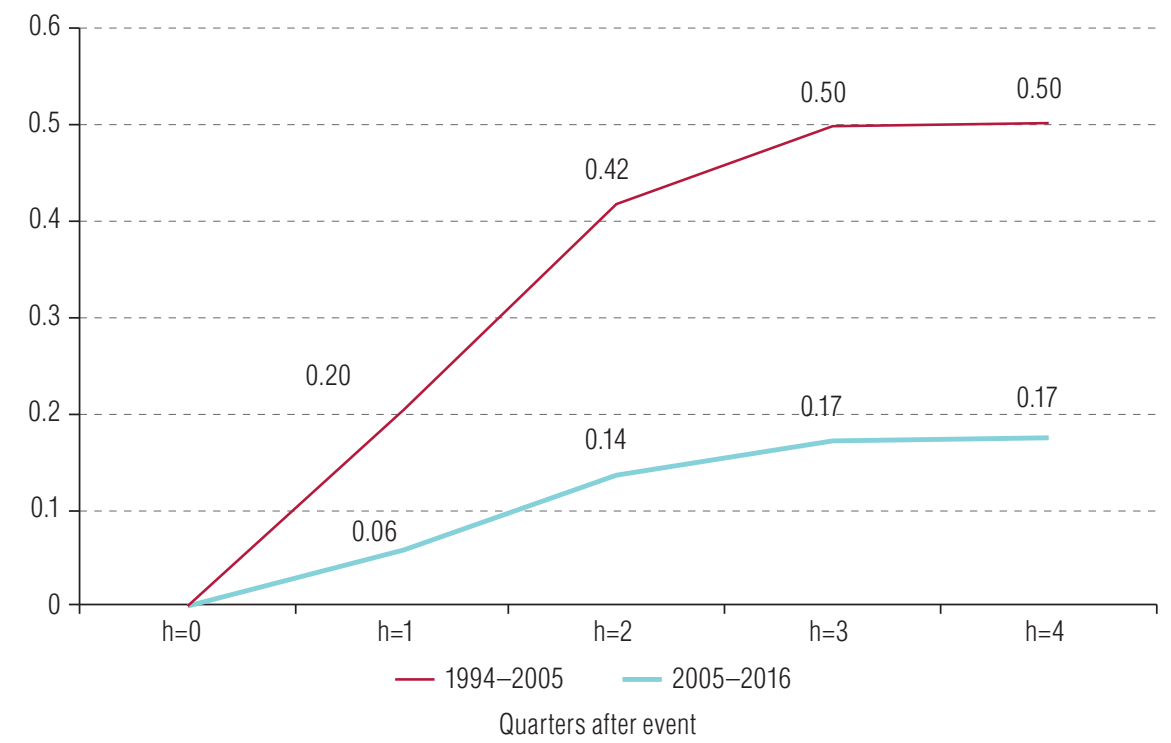

Source: Prepared by the authors.

Note: Cumulative response of consumer prices one, two, three and four quarters after a $1 \%$ increase in the bilateral nominal exchange rate. The following countries are included in the estimates: Argentina, Bolivia (Plurinational State of), Brazil, Bulgaria, Chile, Colombia, Croatia, Hungary, India, Indonesia, Malaysia, Mexico, Paraguay, Peru, Philippines, Poland, Romania, Russian Federation, South Africa, Thailand, Turkey and Uruguay.

Figure A3.3

Exchange rate pass-through by region

(Percentages)

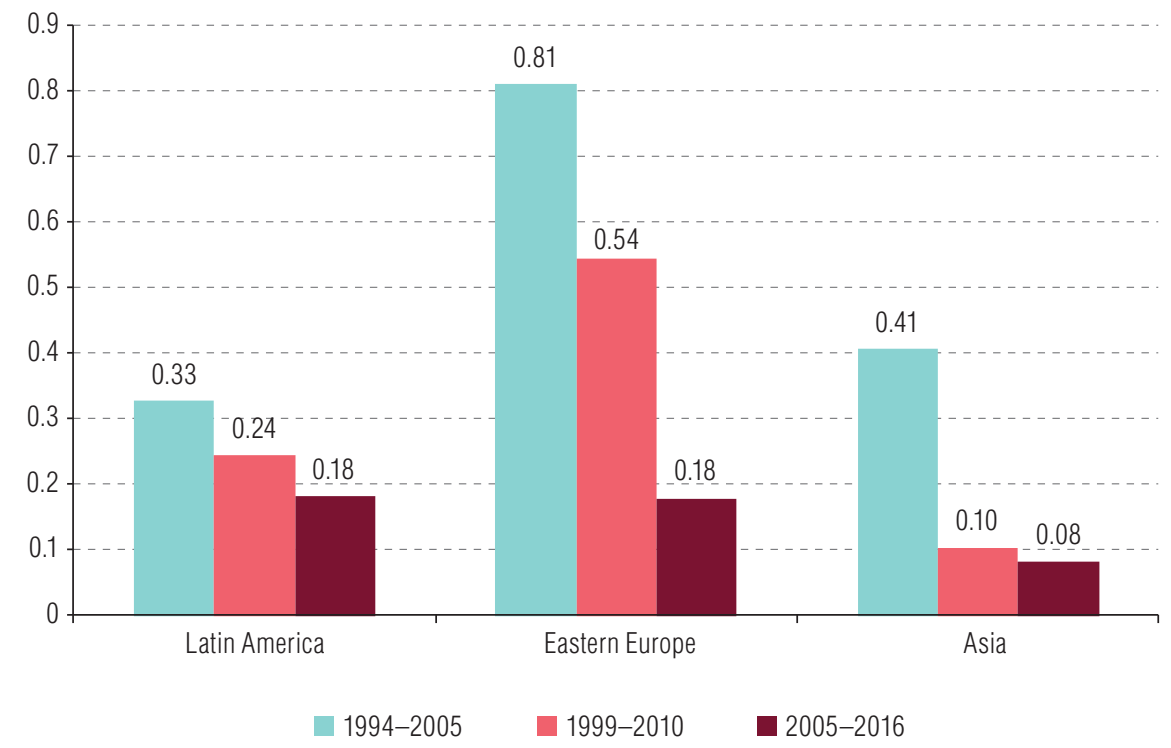

Source: Prepared by the authors.

Note: Cumulative response of consumer prices one year after a $1 \%$ increase in the bilateral nominal exchange rate. Latin America includes: Argentina, Bolivia (Plurinational State of), Brazil, Chile, Colombia, Mexico, Paraguay, Peru and Uruguay; Eastern Europe includes: Bulgaria, Croatia, Hungary, Poland, Romania, Russian Federation and Turkey; Asia includes: India, Indonesia, Malaysia, Philippines and Thailand. 
Figure A3.4

Exchange-rate pass-through, by monetary regime in peripheral countries

(Percentages)

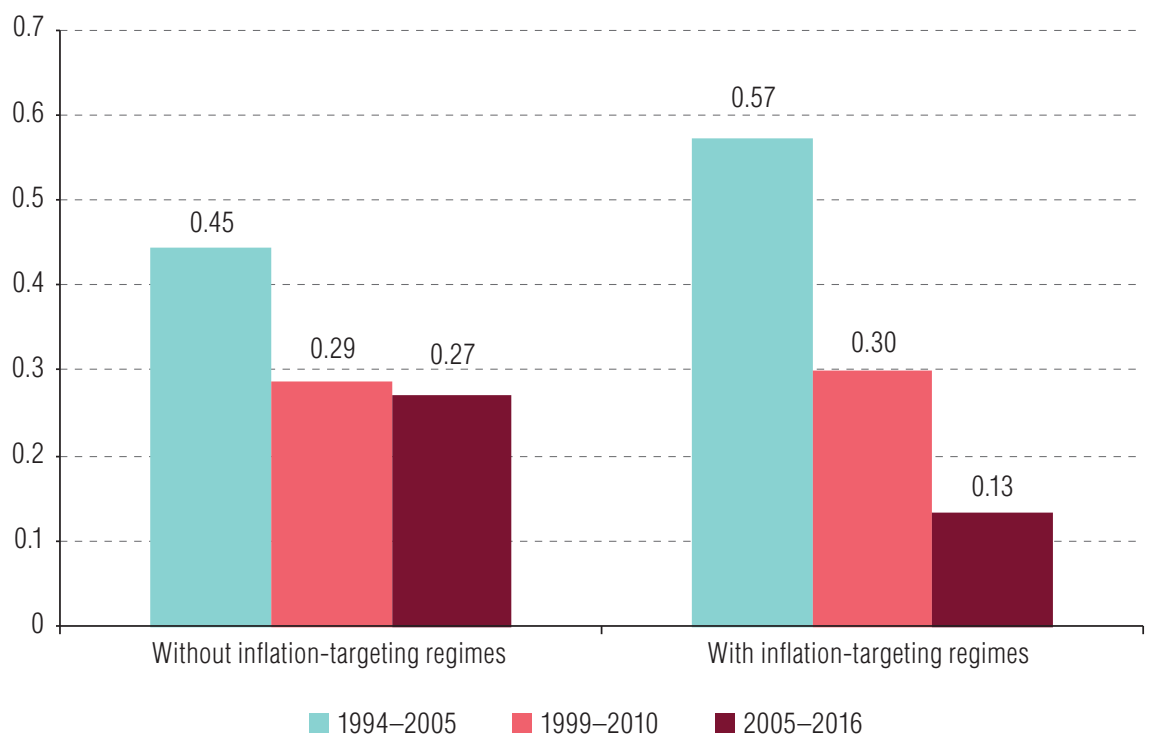

Source: Prepared by the authors.

Note: Cumulative response of consumer prices one year after a $1 \%$ increase in the bilateral nominal exchange rate. Countries with inflation-targeting regimes (implemented in or prior to 2010) include: Brazil, Chile, Colombia, Hungary, Indonesia, Mexico, Peru, the Philippines, Poland, Romania, South Africa, Thailand and Turkey. Countries without inflation-targeting regimes (or with regimes implemented since 2011) include: Argentina, Bolivia (Plurinational State of), Bulgaria, Croatia, India, Malaysia, Paraguay, Russian Federation and Uruguay.

Table A3.1

Determinants of total pass-through of the bilateral nominal exchange rate

\begin{tabular}{|c|c|c|c|c|c|c|c|c|}
\hline $\begin{array}{l}\text { Dependent variable: } \\
\beta_{1, i, \tau}^{h=4}\end{array}$ & 1 & 2 & 3 & 4 & 5 & 6 & 7 & 8 \\
\hline \multirow[t]{2}{*}{ Average depreciation } & $11.606^{\star \star \star}$ & & & & & & $13.372^{\star \star \star}$ & 5.077 \\
\hline & $(1.74)$ & & & & & & (3.33) & (3.51) \\
\hline \multirow{2}{*}{$\begin{array}{l}\text { Bilateral-nominal- } \\
\text { exchange-rate volatility }\end{array}$} & & $2.005^{\star \star}$ & & & & & -0.808 & 1.288 \\
\hline & & $(0.83)$ & & & & & $(0.84)$ & (1.13) \\
\hline \multirow[t]{2}{*}{ Average inflation } & & & $.856^{\star \star \star}$ & & & & 2.098 & 4.669 \\
\hline & & & $(1.31)$ & & & & (2.69) & (2.95) \\
\hline \multirow[t]{2}{*}{ Inflation volatility } & & & & $4.637^{\star \star \star}$ & & & -1.399 & -0.687 \\
\hline & & & & $(1.01)$ & & & (1.51) & (1.53) \\
\hline \multirow[t]{2}{*}{ Globalization indicator } & & & & & $-1.452^{* \star \star}$ & & 0.156 & $-1.458^{\star \star \star}$ \\
\hline & & & & & $(0.38)$ & & $(0.11)$ & $(0.33)$ \\
\hline \multirow[t]{2}{*}{ Wage resistance } & & & & & & $0.059^{* *}$ & $0.074^{*}$ & $0.097^{\star \star}$ \\
\hline & & & & & & $(0.03)$ & $(0.04)$ & $(0.04)$ \\
\hline Country fixed effects & No & No & No & No & No & No & No & Yes \\
\hline Time fixed effects & Yes & Yes & Yes & Yes & Yes & Yes & Yes & Yes \\
\hline Observations & 118 & 118 & 118 & 118 & 118 & 118 & 118 & 118 \\
\hline R-squared & 0.844 & 0.785 & 0.867 & 0.813 & 0.801 & 0.786 & 0.787 & 0.897 \\
\hline
\end{tabular}

Source: Prepared by the authors.

Note: The dependent variable is the estimated total pass-through (bilateral nominal exchange rate with the United States) for the window $\tau$ and country $i$. The standard error is shown in parentheses. Significant at $1 \%\left({ }^{(\star \star}\right)$, significant at $5 \%\left(^{(\star)}\right)$ and at $10 \%\left({ }^{*}\right)$. Extreme observations where the exchange-rate pass-through to consumer prices and the wage resistance coefficient were greater than 1 were excluded. 